\title{
Geochemistry of Host and Altered Rocks in the Nahran Area, Tarom Zone (NW Iran): Implication for Determining of Mineralization Processes in the Alteration Environment
}

\author{
Nasrin Bayrami Tosanloo1, Hamid Reza Peyrowan²*, Seyed Jamal Sheikhzakariee1, \\ Ali Reza Jafari Rad ${ }^{1}$ \\ ${ }^{1}$ Department of Geology, Science and Research Branch, Islamic Azad University, Tehran, Iran \\ ${ }^{2}$ Soil Conservation and Watershed Management Research Institute, Tehran, Iran \\ Email: *hrpeyrowan@yahoo.com
}

How to cite this paper: Tosanloo, N.B., Peyrowan, H.R., Sheikhzakariee, S.J. and Rad, A.R.J. (2017) Geochemistry of Host and Altered Rocks in the Nahran Area, Tarom Zone (NW Iran): Implication for Determining of Mineralization Processes in the Alteration Environment. Open Journal of Geology, 7, 374-394.

http://doi.org/10.4236/ojg.2017.73026

Received: September 14, 2016

Accepted: March 27, 2017

Published: March 30, 2017

Copyright $\odot 2017$ by authors and Scientific Research Publishing Inc. This work is licensed under the Creative Commons Attribution International License (CC BY 4.0).

http://creativecommons.org/licenses/by/4.0/

\begin{abstract}
The Nahran area is located in the Northeast of Zanjan in the Northwest of Iran. This area with $20,000 \mathrm{~km}^{2}$ is part of the Tarom volcanic-plutonic zone which lies between the longitudes $49^{\circ} 7^{\prime} 7.8^{\prime \prime} \mathrm{E}$ and $36^{\circ} 41^{\prime} 25.74^{\prime \prime} \mathrm{E}$ near to the Nahran village. The Nahran altered zone is part of large-scale syncline, which is oriented from Sirdan to Altinkosh with an axial length of $9 \mathrm{~km}$. A systematic study of petrographical and geochemical data of Nahran samples reveals they are andesite, trachyandesite to dacite composition and have metaluminous to peraluminous and calc-alkaline affinity. Four alteration zones of propylitic, medium and advanced argillic and silicific zones could be identified in the area. According to our finding, combination of both supergene and hypogene process has an effective role in the development of alteration in the Nahran alteration zone.
\end{abstract}

\section{Keywords}

Tarom, Nahran, Alteration, Hypogene, Supergene

\section{Introduction}

The Tarom Mountains, which cover most of the Zanjan quadrangle, are western extention of central Alborz Mountain. According to structural divisions of Iran proposed by Nabavi (1976), this area is part of western Alborz structural zone (Alborz-Azerbaijan zone) [1]. The Nahran alteration zone is located approximately $100 \mathrm{~km}$ northeast of the city Zanjan and covers $20,000 \mathrm{~km}^{2}$ area within the Tarom volcano-plutonic zone (Figure 1). This zone lies between the longitudes 
$49^{\circ} 7^{\prime} 7.8^{\prime \prime} \mathrm{E}$ and $36^{\circ} 41^{\prime} 25.74^{\prime \prime} \mathrm{E}$ near to Nahran village. The Nahran alteration zone is cutted by Nahran River and can be traced as long-scale white narrow ribbon along the footage of Tarom Mountains. The Nahran alteration zone is mainly hosted by Paleogene tuffs, which have been intruded by younger acidic trusions

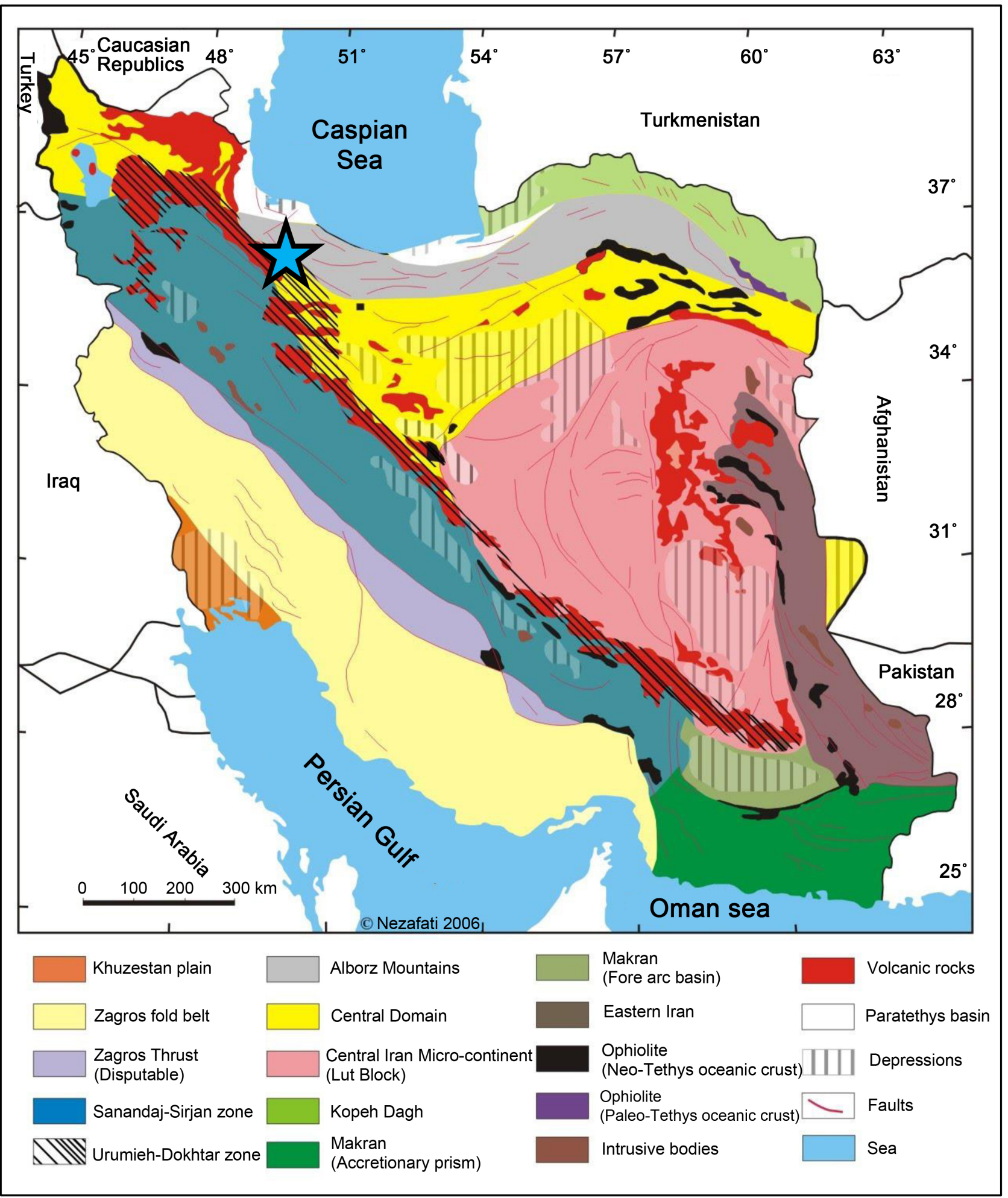

Figure 1. Iran structural zones map, (Nezafati 2006). 
and widely affected by hydrothermal alteration. Alteration haloes are important in mineral exploration, as they increase the size of the target mineralized zone. For example, some of the altered host rocks in the Tarom contain anomalous concentrations of gold, which are far-removed from the mineralized veins. Despite to their economic importance for alunite and kaolinite, the Nahran alteration zone is less studied so far and there are many unknown genetic processes involved in the development of alteration areole. This study normally focuses on the alteration zone of Nahran area with the aim of identifying the compositions of source rock (protolith) and the nature of physicochemical changes during alteration [2].

\section{Methodology and Analytical Procedures}

In this research, extensive field works include preparation of new geological map were combined with systematic and random sampling to aim multidisciplinary approach of this research. After petrographical observation, 25 samples were selected for geochemical analysis. Trace and Minor element for selected samples were analyzed using combined ICP-AES and inductively coupled plasma mass spectrometry (ICP-MS) methods, at the Geological Survey of Iran. However, major elements were determined by wavelength dispersive XRF, using an automated Philips PW 1480 spectrometer in the Geological Survey of Iran.

\section{Discussion}

\subsection{Geology of Nahran Kaolinite-Alunite District}

The Nahran altered zone is located in the NWW border of a large-scale, syncline which oriented from Sirdan to Altin Kosh with an axial length of $9 \mathrm{~km}$. The Dip of layer planes ranges between 40 to 60 towards the NE (Figure 2). The larg intrusion massif (Kohe Ghajar) is a which situated in the contact zone of Nahran alteration and extent southeastern to Sirdan, Hasan Abad and Kamar roud villages (Figure 3). In the Nahran area, there are several huge alunite deposite within the Eocene volcano-clastic rocks. It is considered that the emplacement of larg intrusion massif (Kohe Ghajar) into Eocene volcano-clastic rocks promotes the hydrothermal alteration and alunite formation. The alteration areole with $2 \mathrm{~km}$ long and $1 \mathrm{~km}$ width and with average thickness of $265 \mathrm{~m}$ have developed within the black to grey tuffs of E and EK1 unit in the proximity of quartz monzonite and quartz syenite of intrusion massif of the Kohe Ghajar [3] [4]. In the Nahran area, there are regular hydtothermal alteration zonations from bottom to top including:

1) Propylitic unit which observed in the proximity of intrusion massif and bottom of the Nahran altered zone within the andesitic tuffs.

2) Medium argillic alteration unit with $210 \mathrm{~m}$ thickness.

3) Advanced argillic alteration unit containing quartz bearing alunite with 25 $m$ thickness.

4) Silicic alteration unit which lie as Hard and brittle cap rock in the top of other alteration unit. The total thickness of this cap rock range between 25 to 30 $\mathrm{m}$ and consist of silica with minor alunite. The Nahran silicic unit has low purity 


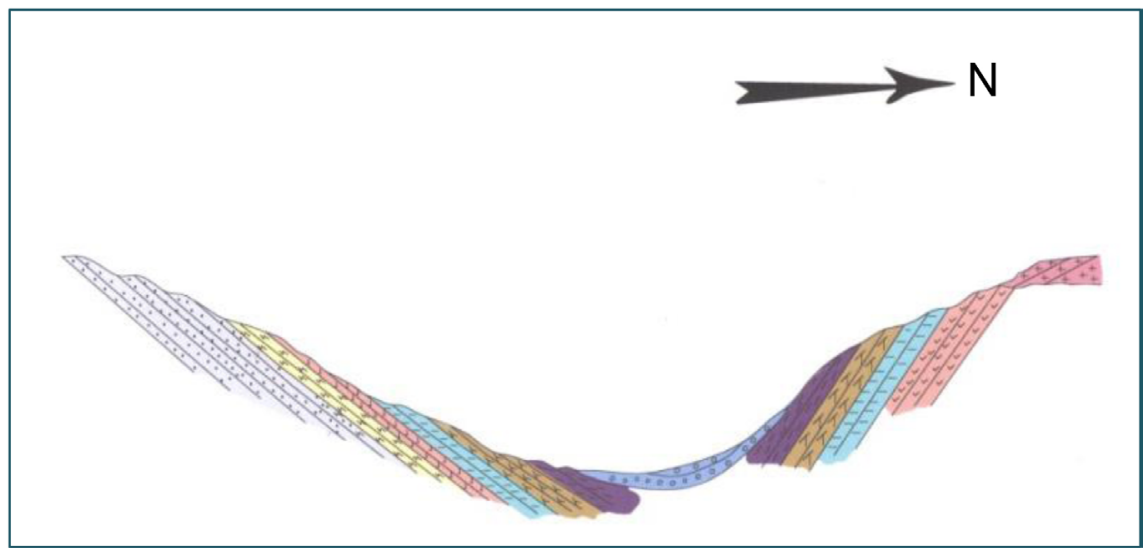

Rhyolite-Dacite lava

Green sandy to gonclomerate tuffs Upper sandy-silty Violet tuffs

Upper grey tuffs
Alunite zone

Lower violet tuffs

Gypse and- limonite bearing zone

Grey lower Tuffs which contain Gypseous in the upper part

Figure 2. Geological cross-section of Sirdan-Altin Kosh syncline (after., Navaii., 1983).

respect to other neighbor region such as Yuzbashi Chay and Sirdan areas. However, their low silica content suitable for exploration of silica rock [5] [6].

\subsection{Classification and Nomenclature of Less Altered Host Rock}

Several rock classification diagrams are used for classification and nomenclature of less altered extrusive rocks of the Nahran area. They are including:

-Middlemost (1994) classification:

According to $\mathrm{Na}_{2} \mathrm{O}+\mathrm{K}_{2} \mathrm{O}$ vs. $\mathrm{SiO}_{2}$ diagram of Middlemost [7] [8] [9], the samples fall in the andesite, trachyandesite and near to dacite boundary line field (Figure 4).

-Winchester and Floyd (1977) classification:

The $\mathrm{Zr} / \mathrm{TiO}_{2}{ }^{*} 0.0001$ vs. Nb/Y diagrams of Winchester and Floyd (1977) [10] is more accurate then $\mathrm{Na}_{2} \mathrm{O}+\mathrm{K}_{2} \mathrm{O}$ vs. $\mathrm{SiO}_{2}$ diagrams since $\mathrm{Zr}$ and Ti are not mobile elements. According to this diagram all samples fall in the andesite, Trachy-andesite and dacite regions (Figure 5).

\subsection{Determination of Magmatic Series}

One of the main objects in the petrological studies is determination of magmatic series. According to Kuno (1968), a magmatic series is a group of rocks that share some chemical (and perhaps mineralogical) characteristics and shows a consistent pattern on a variation diagram [11], suggesting a genetic relationship. Hovewer, new funding shows other parameter such as magma assimilation, different rates of partial and magmatic contamination could be create false magma series and grouping of different magmatic rock in the same magmatic association which not 


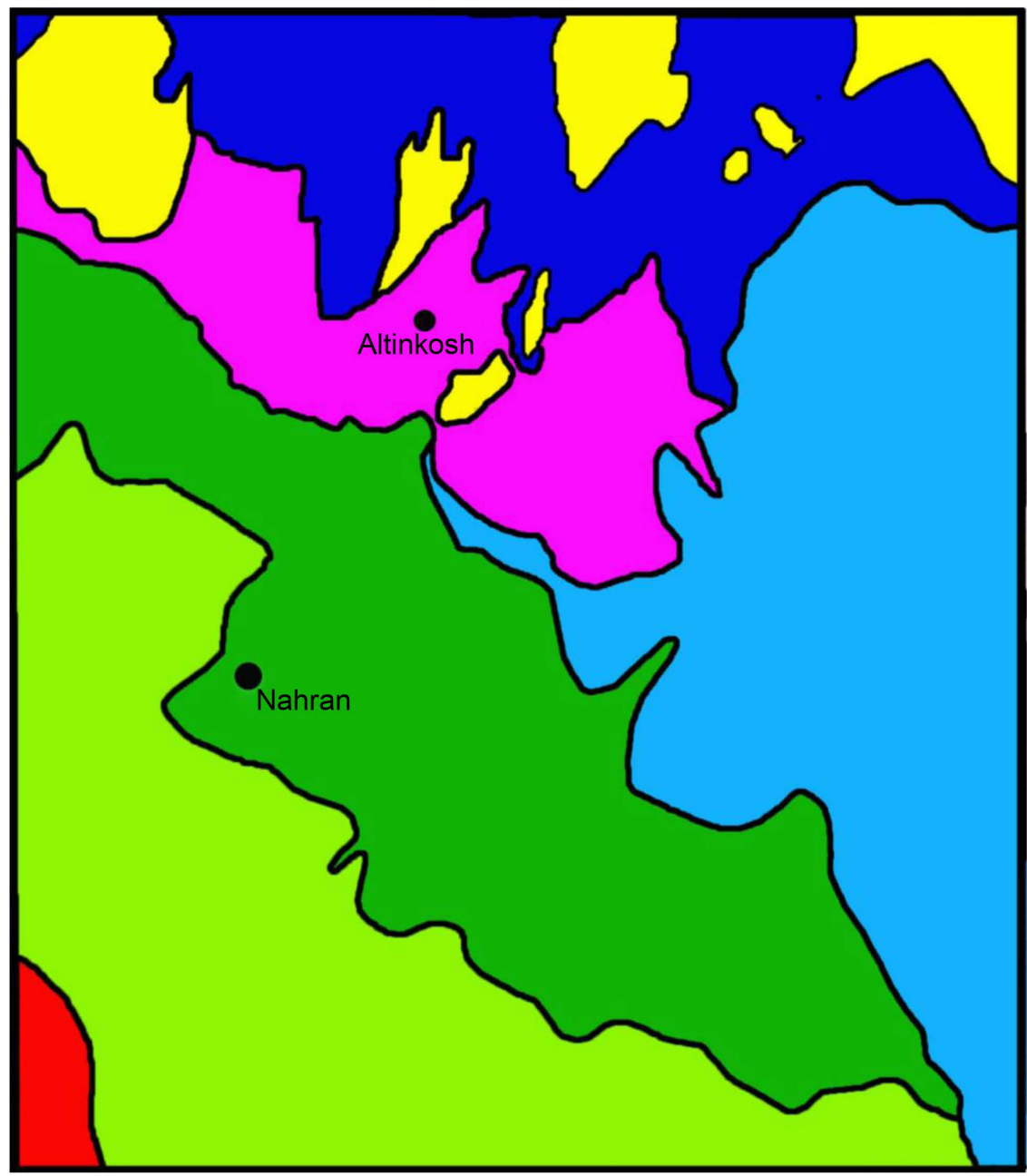

Quaternary terrace and alluvium,

$\mathrm{Ng}^{2}$ unit, Neogene red color sediments,

$\mathrm{Ng}^{1}$ unit, Neogene red color, $\square$ Karaj Formation, Amand member, $\mathrm{Ea}^{4}$ unit, $\square$ Karaj formation, Kordkand member, $\mathrm{Ek}^{1}$ unit, $\square$ Eocene mudstone tuffs, $\square$ granodiorite

Figure 3. Geological map of Kohe Ghajar Nahran-Altin Kosh.

evuloved from same parent magma. In order to determination of magma series of Nahran volcanic rock several different diagrams are used as follow:

-Miyashiro (1974) diagram:

The $\mathrm{FeO}_{\mathrm{t}} / \mathrm{MgO}$ versus $\mathrm{SiO}_{2}$ diagram can be discriminate alkaline and subalkaline rocks. Geochemical classification using Miyashiros (1974) scheme categorises the composition of the Nahran volcanic rock fall in the calc-alkaline field (Figure 6).

-AFM diagram (Irvin and Baragar, 1971):

The "AFM" (Alkalis- $\Sigma \mathrm{FeO}-\mathrm{MgO}$ ) diagram proposed by Irvin and Baragar (1971) can be discriminate tholeiitic, calc-alkaline or Shoshonite affinity of Subalkaline rocks [12]. On the AFM diagram, the Nahran samples plot within the calc-alkaline field. One sample plot on the tholeiit field (Figure 7).

$-\mathrm{K}_{2} \mathrm{O}$ versus $\mathrm{SiO}_{2}$ diagram Peccerillo and Taylor (1976):

The $\mathrm{K}_{2} \mathrm{O}$ versus $\mathrm{SiO}_{2}$ plot showing a rock suite may be subdivided geochemically 
N. B. Tosanloo et al.

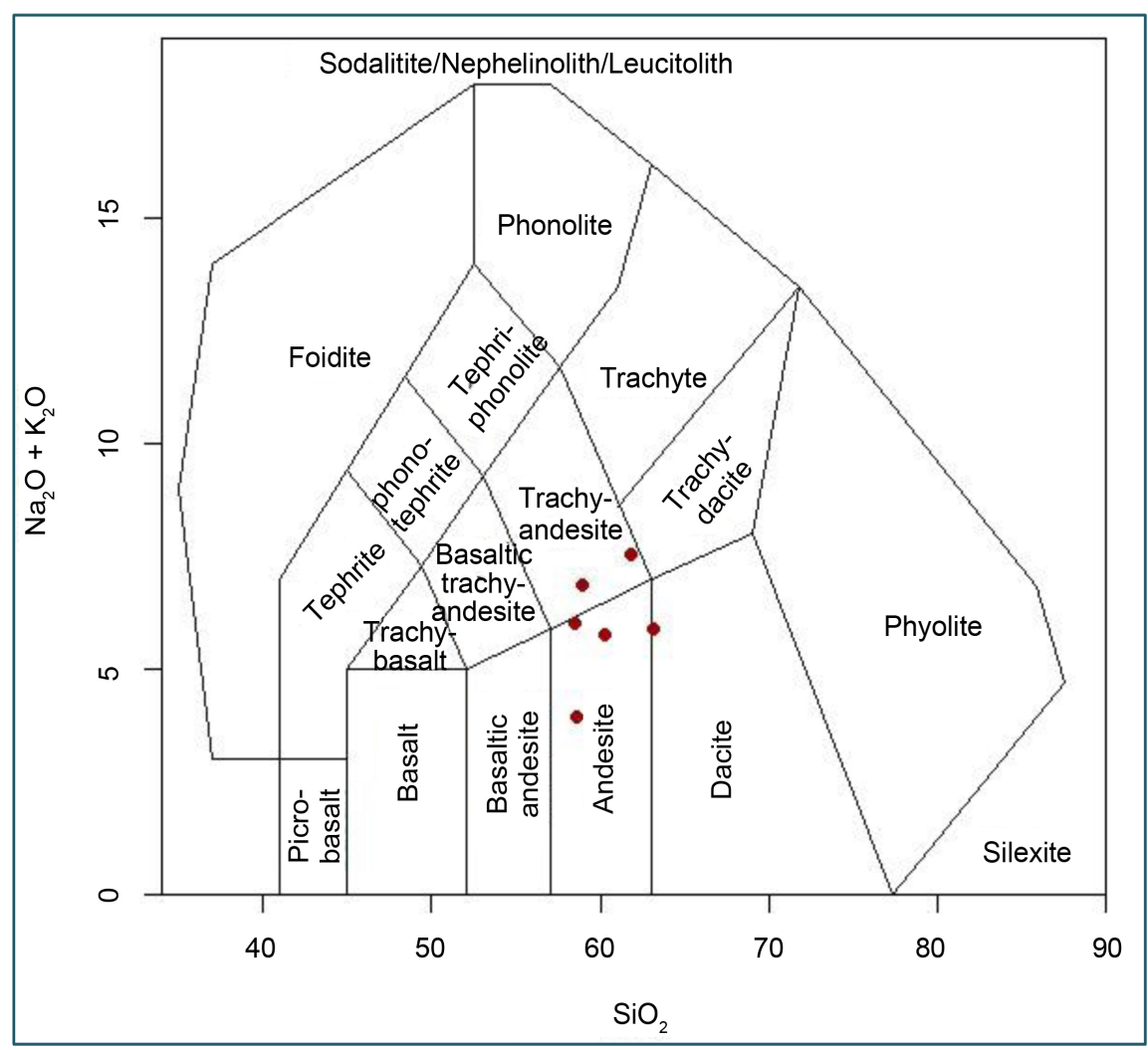

Figure 4. $\mathrm{Na}_{2} \mathrm{O}+\mathrm{K}_{2} \mathrm{O}$ vs. $\mathrm{SiO}_{2}$ diagram of Middlemost (1994).

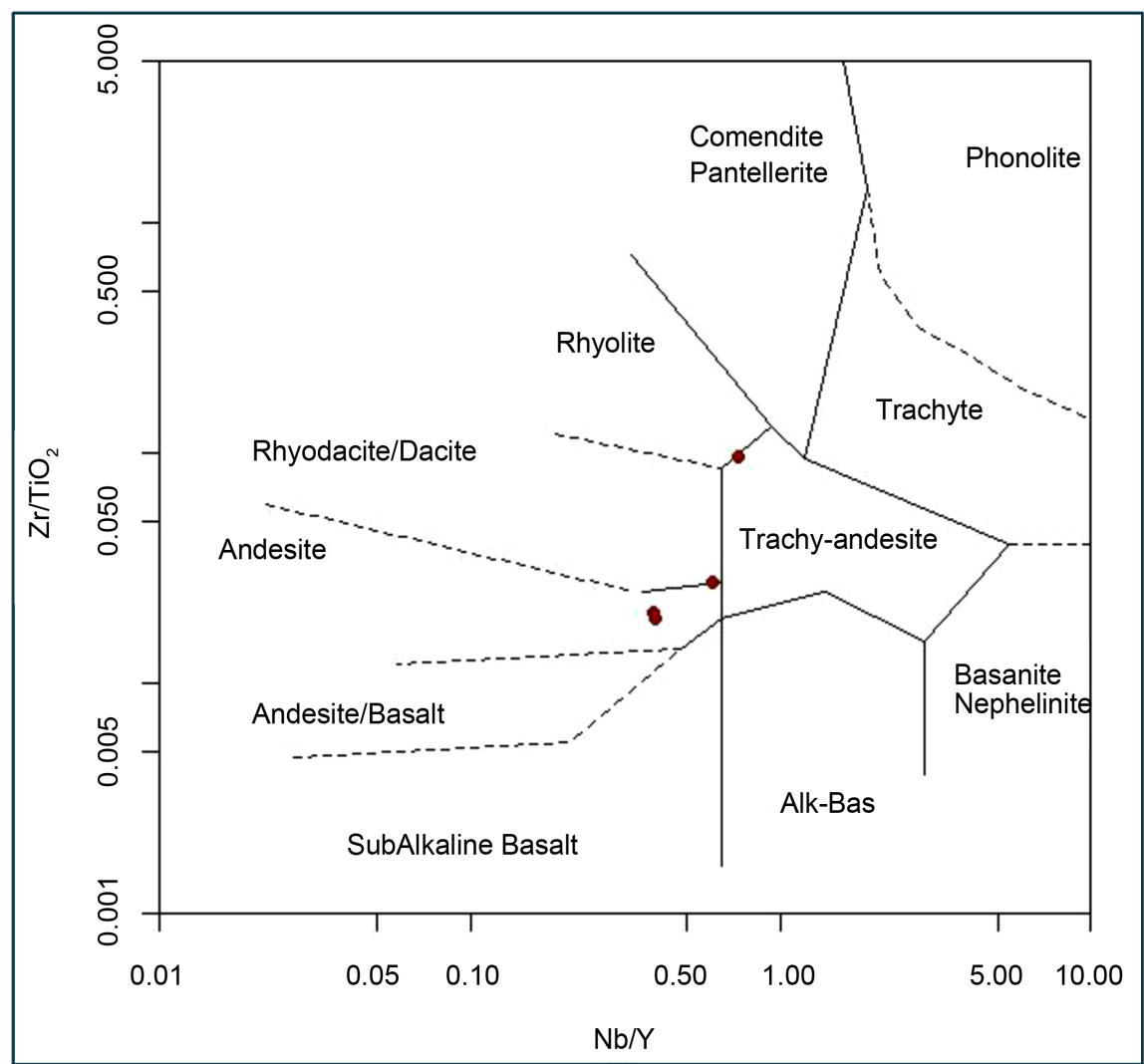

Figure 5. The $\mathrm{Zr} / \mathrm{TiO}_{2}{ }^{\star} 0.0001$ vs. $\mathrm{Nb} / \mathrm{Y}$ diagrams of Winchester and Floyd (1977). 


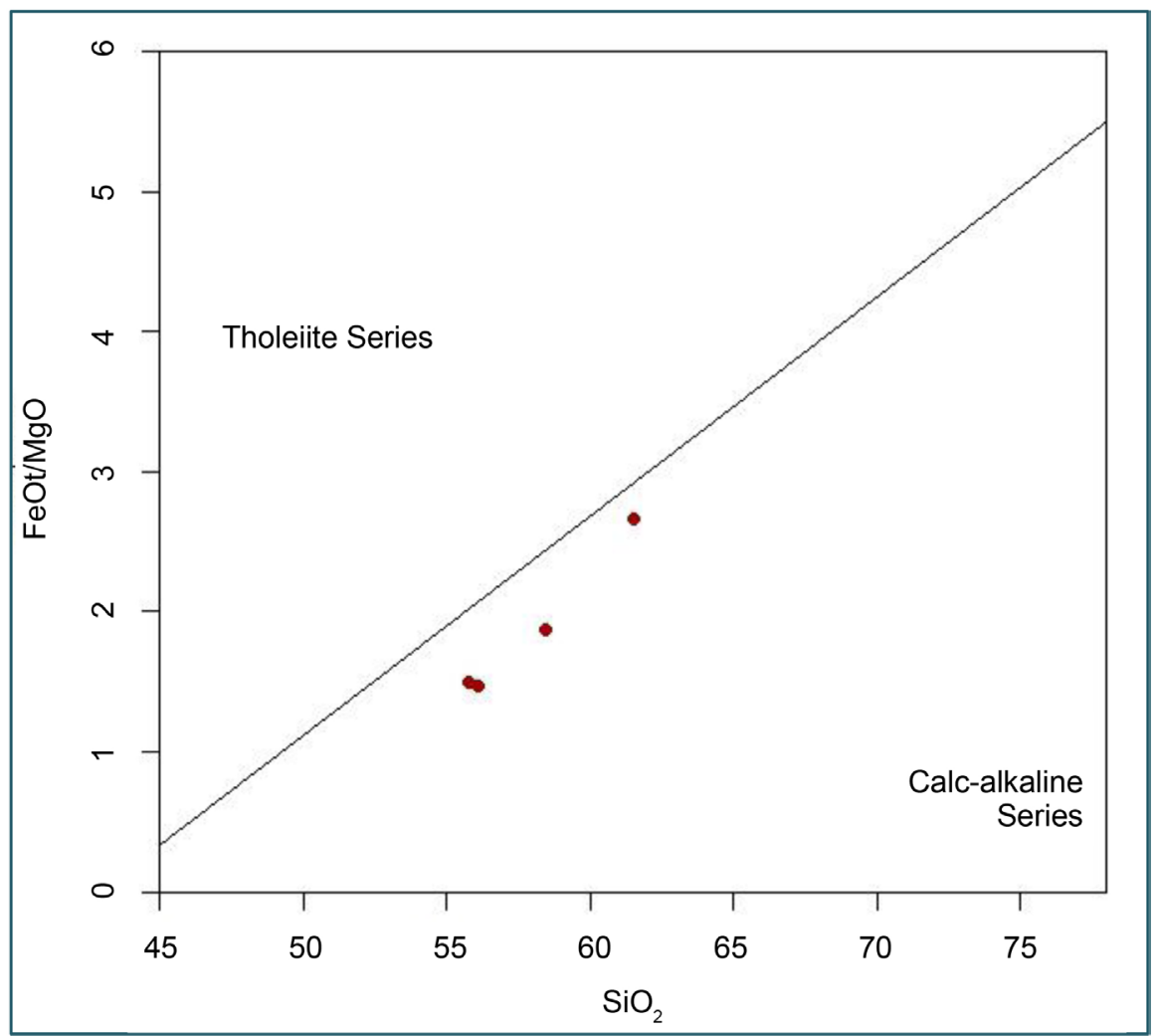

Figure 6. The $\mathrm{FeO}_{\mathrm{t}} / \mathrm{MgO}$ versus $\mathrm{SiO}_{2}$ diagram of Miyashiro (1974).

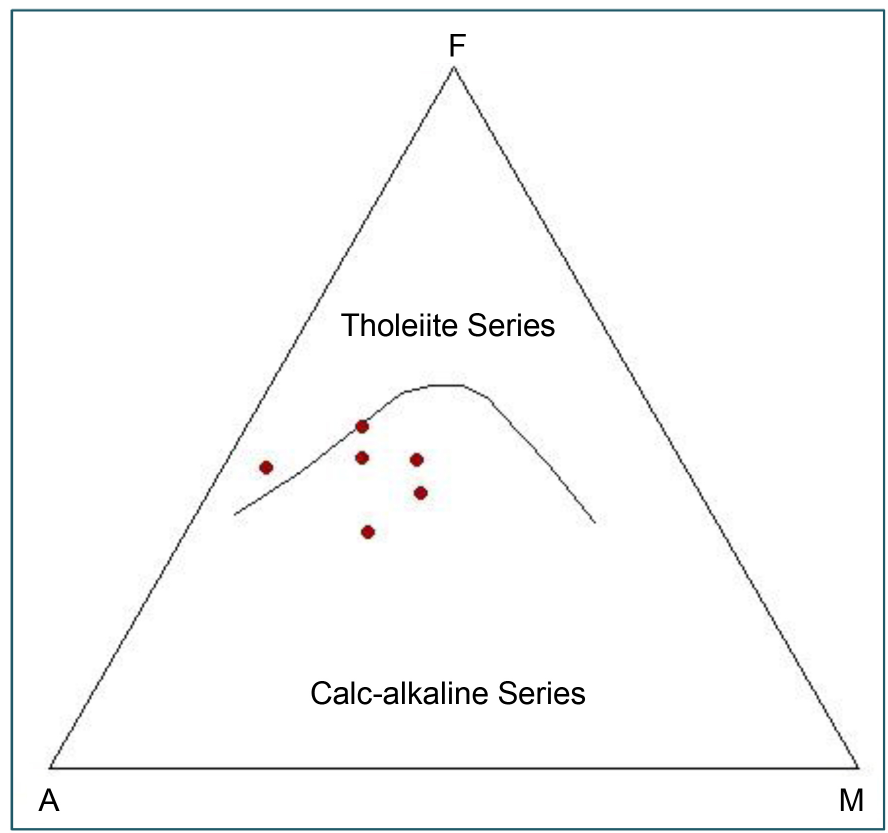

Figure 7. AFM diagram (Irvin and Baragar, 1971).

into low- $\mathrm{K}$, medium- $\mathrm{K}$ and high- $\mathrm{K}$ associations. In the $\mathrm{K}_{2} \mathrm{O}$ versus $\mathrm{SiO}_{2}$ diagram the Nahran volcanic rocks shows calc-alkaline, high calc-alkaline and shoshonite affinity (Figure 8).

-Aluminium saturity index: 
The volcanic rocks divided to peraluminous, metaluminous and peralkaline on the basis of the molecular proportions of $\mathrm{AI}, \mathrm{Ca}, \mathrm{Na}$ and $\mathrm{K}$, expressed in the form $\mathrm{A} / \mathrm{CNK}>1, \mathrm{~A} / \mathrm{CNK}-1, \mathrm{~A} / \mathrm{CNK}<1$, respectively. The Nahran volcanic rock has metaluminus and peraluminus affinity (Figure 9 and Figure 10).

\subsection{Tectonic Setting of Nahran Volcanic Rocks}

In order to define the tectonic setting of Nahran volcanic rocks several tectonic discriminate diagram have been used they are include:

- The $\mathrm{FeO}(\mathrm{t})-\mathrm{MgO}-\mathrm{Al}_{2} \mathrm{O}_{3}$ ternary diagram.

The $\mathrm{FeO}(\mathrm{t})-\mathrm{MgO}-\mathrm{Al}_{2} \mathrm{O}_{3}$ ternary diagram proposed by Pearce et al. (1977) and can be discriminate volcanic rocks of different tectonic setting include: 1) islands of mid ocean spreading center, 2) orogenic, 3) mid ocean ridge, 4) oceanic islands and 5) continental setting (Figure 11).

The Nahran volcanic samples plot in the orogenic and islands of mid ocean spreading center fields.

- The $\mathrm{TiO}_{2}-\mathrm{MnO}^{\star} 10-\mathrm{P}_{2} \mathrm{O}_{5}{ }^{\star} 10$ ternary diagram.

Mollen (1983) used $\mathrm{TiO}_{2}-\mathrm{MnO}^{\star} 10-\mathrm{P}_{2} \mathrm{O}_{5}{ }^{\star} 10$ to discriminate between tectonic setting for volcanic rocks from different tectonic setting include: 1) OIT (oceanic island tolleiite), MORB (mid ocean ridge basalt), IAT (island arc tolleiite), CAB (calc-alkaline basalt) and OIA (oceanic island andesite) (Figure 12). The Nahran volcanic rocks fall in the oceanic island alkaline basalt and calc-alkaline basalts.

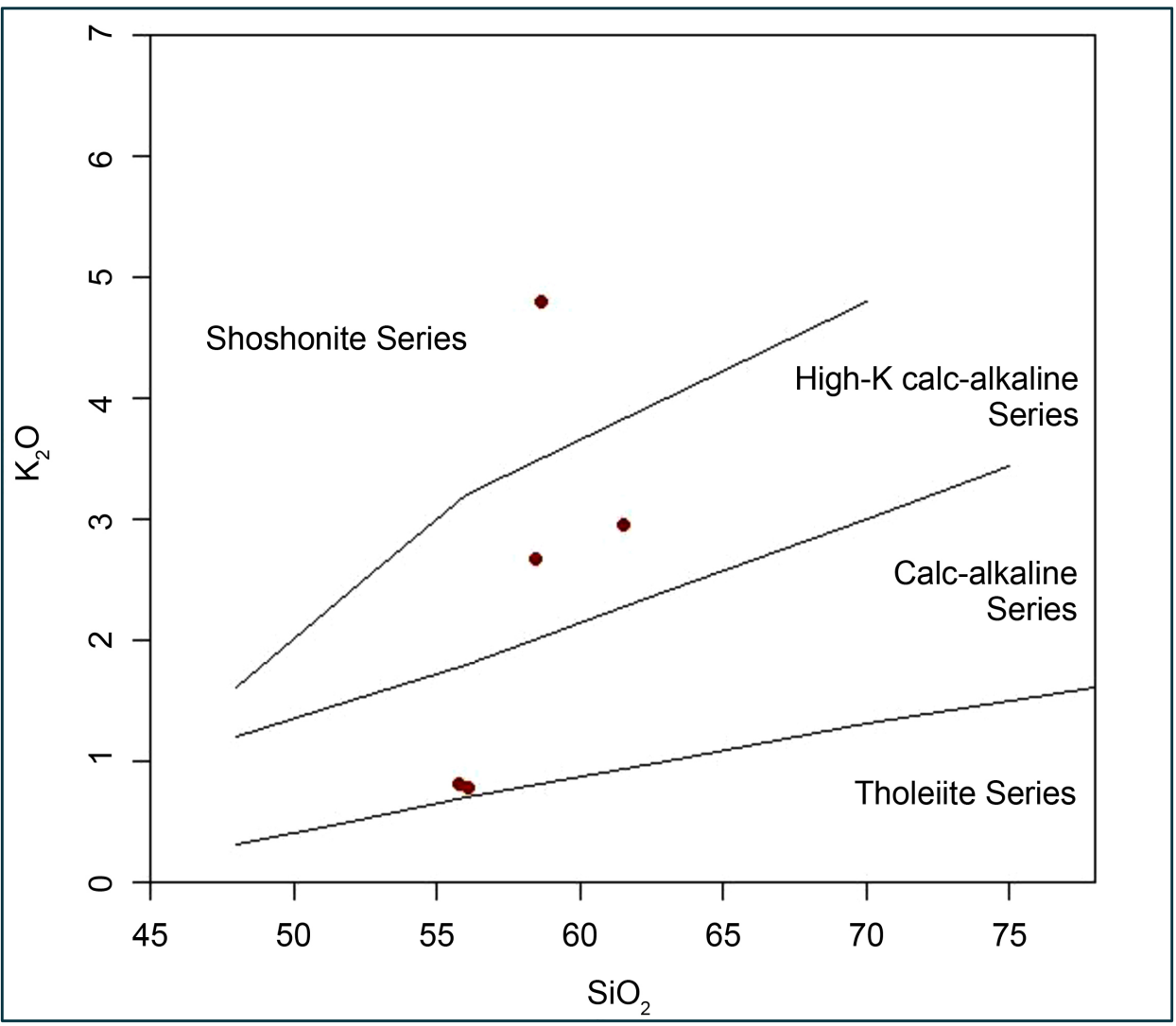

Figure 8. The $\mathrm{K}_{2} \mathrm{O}$ versus $\mathrm{SiO}_{2}$ diagram (Peccerillo and Taylor 1976). 


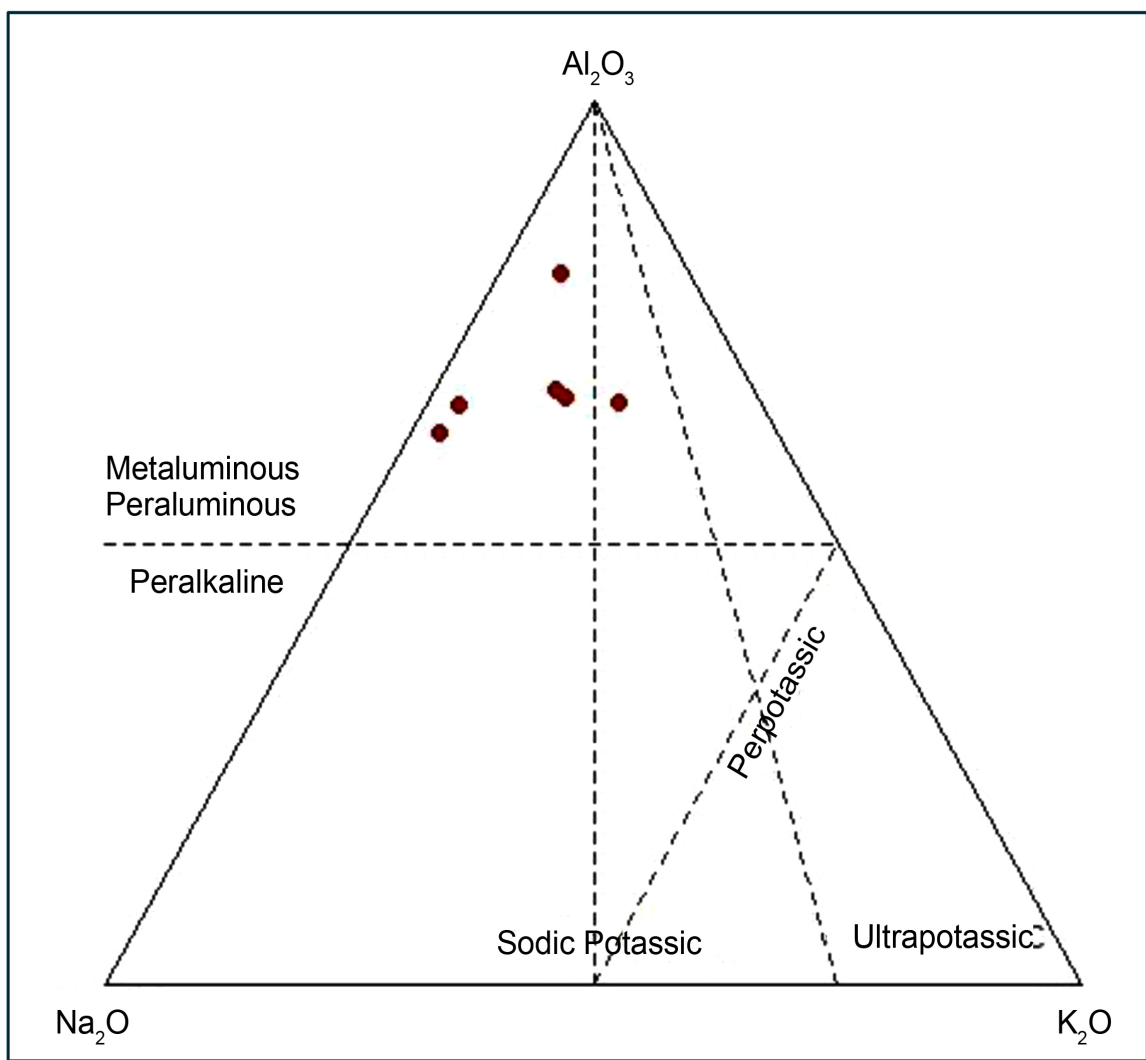

Figure 9. The $\mathrm{Na}_{2} \mathrm{O}-\mathrm{Al}_{2} \mathrm{O}_{3}-\mathrm{K}_{2} \mathrm{O}$ ternary diagram.

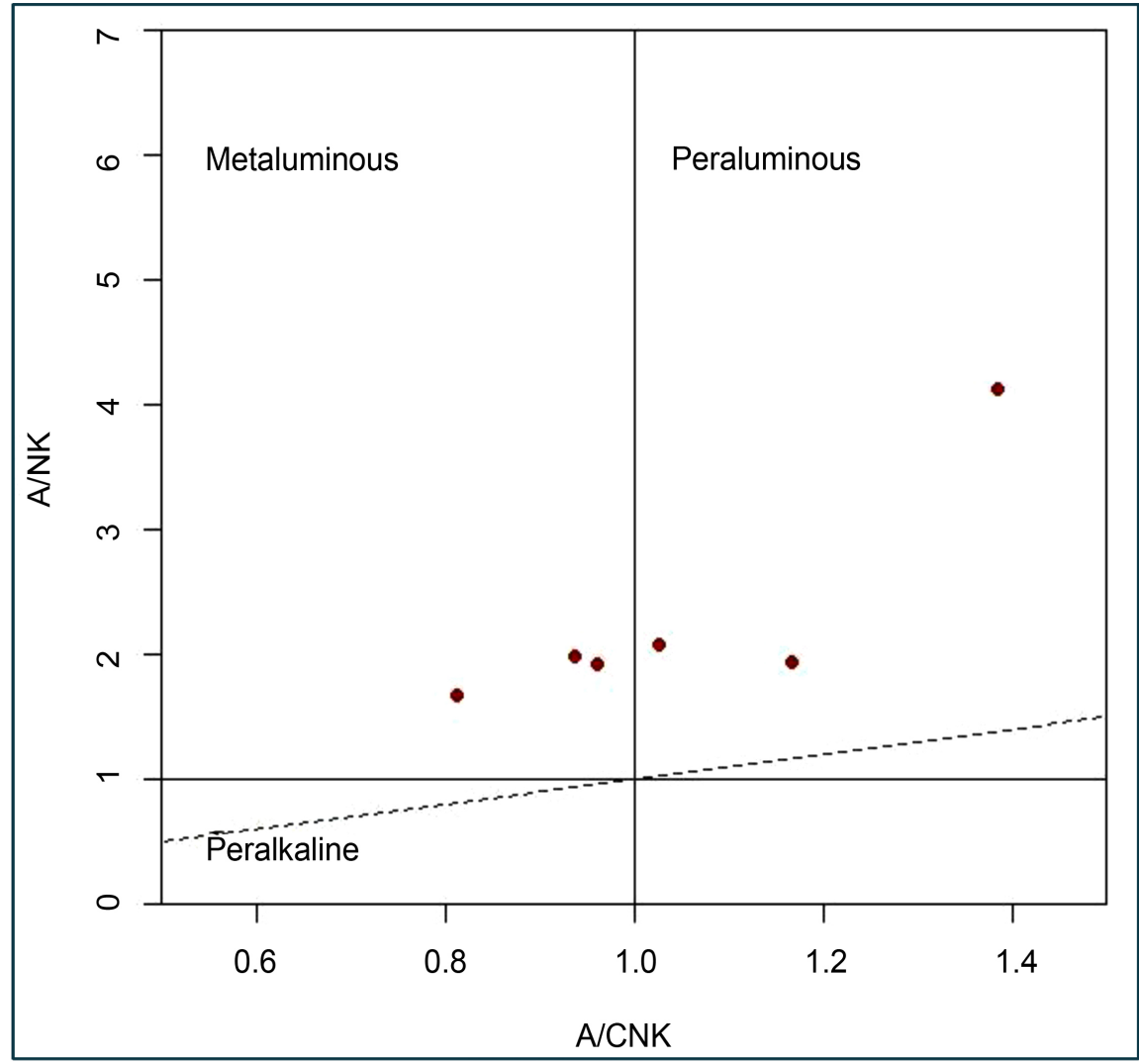

Figure 10. The A/NK versus A/CNK diagram (Shand, 1943). 


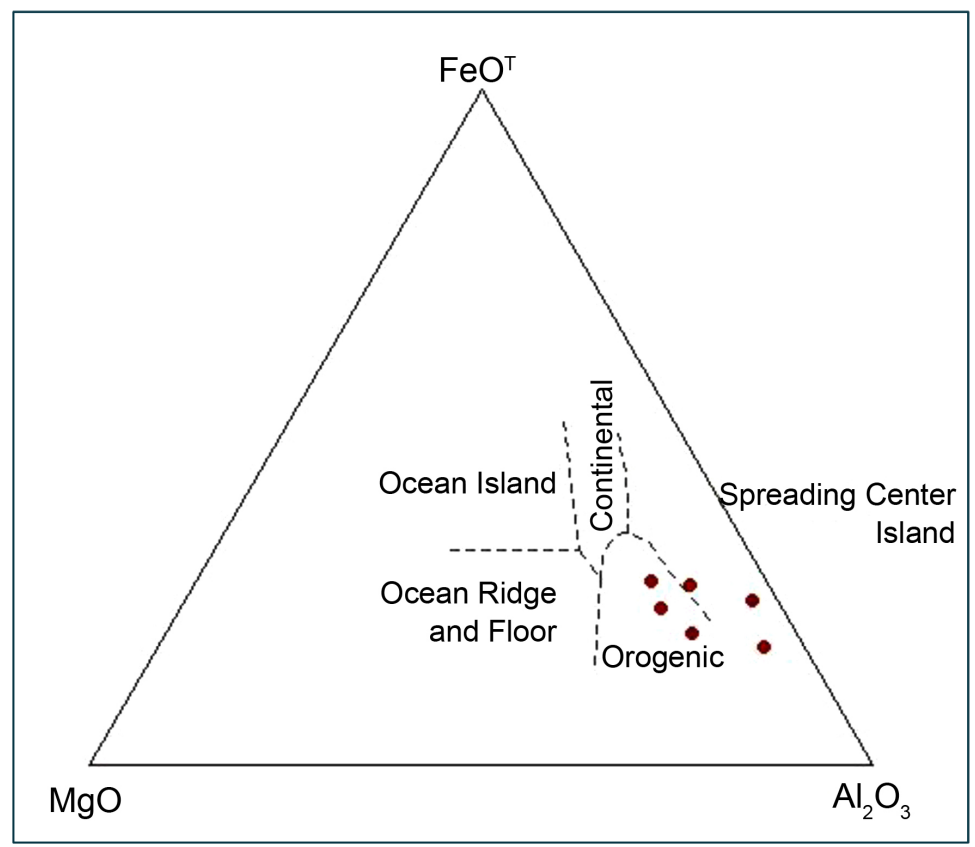

Figure 11. The $\mathrm{FeO}(\mathrm{t})-\mathrm{MgO}-\mathrm{Al}_{2} \mathrm{O}_{3}$ ternary diagram, Pearce et al. (1977).

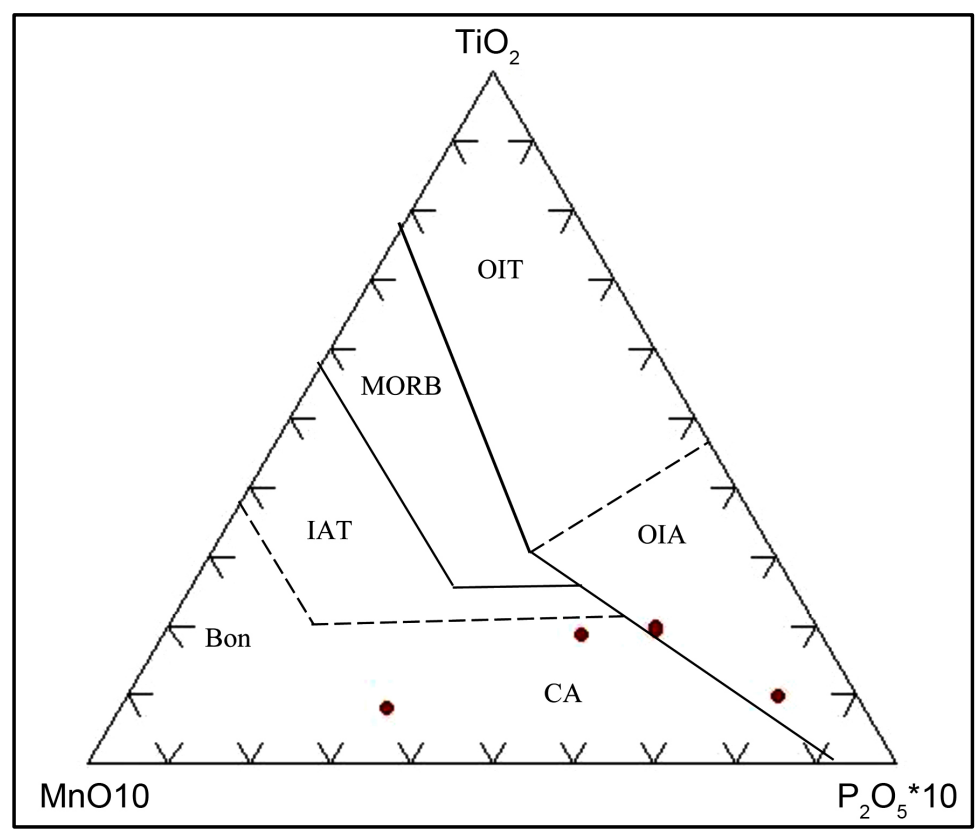

Figure 12 . $\mathrm{TiO}_{2}-\mathrm{MnO}^{\star} 10-\mathrm{P}_{2} \mathrm{O}_{5}{ }^{\star} 10$ ternary diagram, Mollen (1983).

\subsection{Spider Diagrams}

The spider diagrams are used for determination of the petrological process and comparison of different tectonic setting. The rare earth element concentration in the Nahran rocks are normalize to a common reference standard such as chonderite, primitive mantle and MORBs, in order to recognization of magma evolution process such as fractional crystallization, partial melting and magma assimilation.

-Chonderite normalization for Nahran volcanic rocks. 
Thampson et al. (1980; 1984) [13] [14] are used common chonderites values to proposed a chonderite normalized spider diagrams. Thompson (1982) [15] proposed that normalization to chondrite values may be preferable to primitive mantle compasation since chondrite value are directly measured rather estimited. In this diagram, compatibility increase from left to right. Chonderite normalized spider pattern of Nahran volcanic rocks show relative enrichment in the incompatible element respect to chonderite (Thamson, 1982) [15]. Relative enrichment in the incompatible element indicates parent magma was not primary magma and direct product of mantle melting. As mentioned above partial melting of parent rocks was medium. The concenterations of LILE depend to aqueous fluid phases in contrast concenterations of HFS element controlled by chemical composition of source rocks and magmatic evolution reactions and crystal-melt processes, respectively. The LILE enrichment of Nahran volcanic rock in the Chonderite normalized diagram indicate role of crustal contamination in the magmatic evolution. The LILE and HFS amount of Nahran volcanic rock show lowest difference which indicates medium partial melting of source region of parent magma (Figure 13).

-Normalization of Nahran volcanic rocks to mid ocean ridge basalts (MORB).

Pearce (1983) determine normalizing values of MORB and provided most appropriate pattern for evolved basalt, andesite and mid ocean ridge basalts [16]. The element are ordered so that the most mobile elements $(\mathrm{Sr}, \mathrm{K}$, and $\mathrm{Ba}$ ) are placed at the left of the diagram and in order of increasing incompatibility (Rollinson, 1993) [17]. MORB normalized spider pattern of Nahran volcanic rocks show relative enrichment in the LILE respect to HFS elements. The LILE and lithophile elements (especially Th) enrichment indicate the role of crustal contamination or other primary magma contaminative processes in the magma evolution. The diagram show descending pattern from mobile to immobile elements

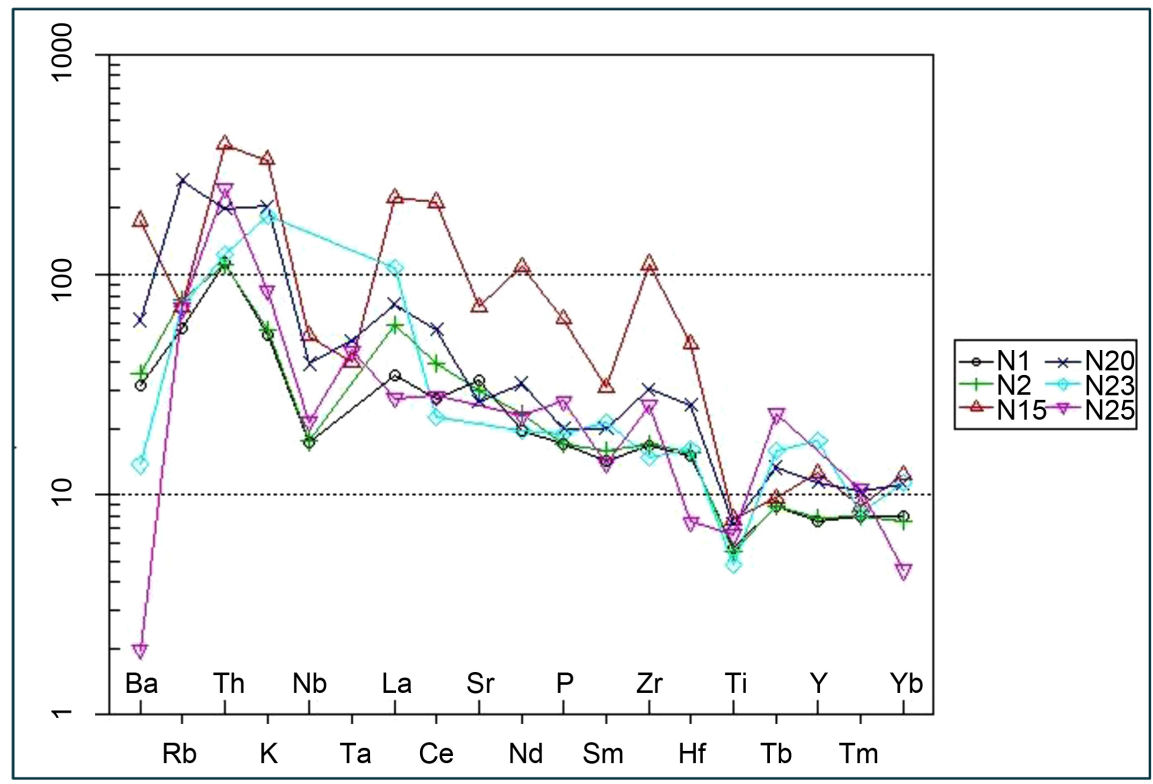

Figure 13. Spider plot-chondrites (Thompson 1982). 
and more of 10 times enrichment in $\mathrm{Ba}, \mathrm{Rb}$, Th and $\mathrm{K}$ respect to MORB. The relative depletion in the $\mathrm{Nb}$, has been explained by retention of a refractory phase in the source in which those elements are highly compatible, such as rutile. However, it can be in related to melting or fractional crystallization of $\mathrm{Nb}$ bearing mineral phases (Figure 14).

-Normalization Nahran volcanic rock to Primary mantle.

Wood et al. (1979) are used estimated composition of mantle before continental crust formation as mean for comparing composition variations between basic lavas and intrusions [18] [19] [20]. In this diagram, elements are arranged in order of increasing compatibility with respect to a small percentage melt of the mantle. Primary mantle normalized pattern for Nahran volcanic rocks show descending trend with relative enrichment in the compitable element. The week enrichment in the $\mathrm{Cs}$ and $\mathrm{K}$ indicate negligible crustal contamination and low crystal fractionation. Negative $\mathrm{Nb}$ anomaly is typical of continental crust rocks and demonstrate role of contamination process in the magma evolution. According to Wilson (1989) [21] enrichment of $U, K$ and Th respect to primary mantle may indicate mantle metasomatism by released fluids from subducting slab (Figure 15).

\subsection{Chemical Classification of Different Alteration Units}

Different alteration units can be distinguished and discriminated based on chemical features. Hydrothermal fluid changes of major and minor elements in the host rocks of the Nahran alteration zone. For classification of altered rocks used different diagram include:

-AKF diagram.

The AKF diagram discriminate Argillic, Advanced Argillic and sericitic zones. the advanced argillic restricted to A side (aluminium silicate) in the AKF diagram

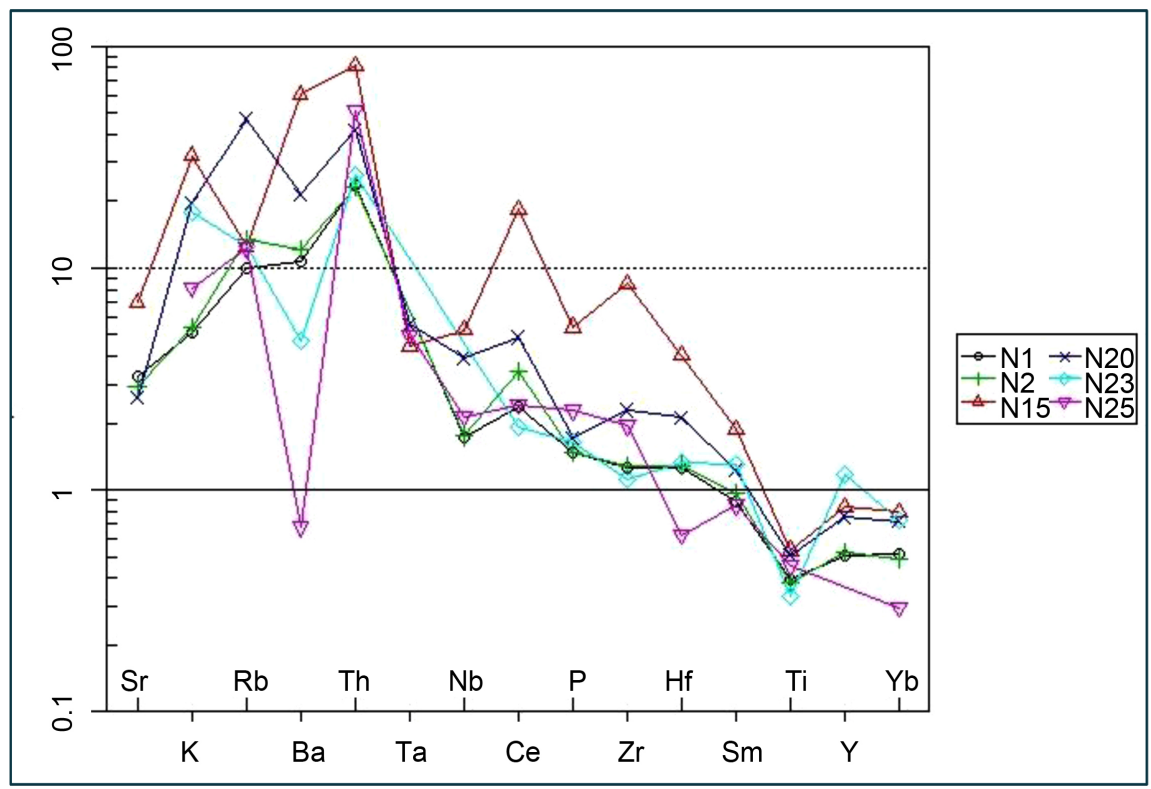

Figure 14. Spider plot-MORB (Pearce 1983). 


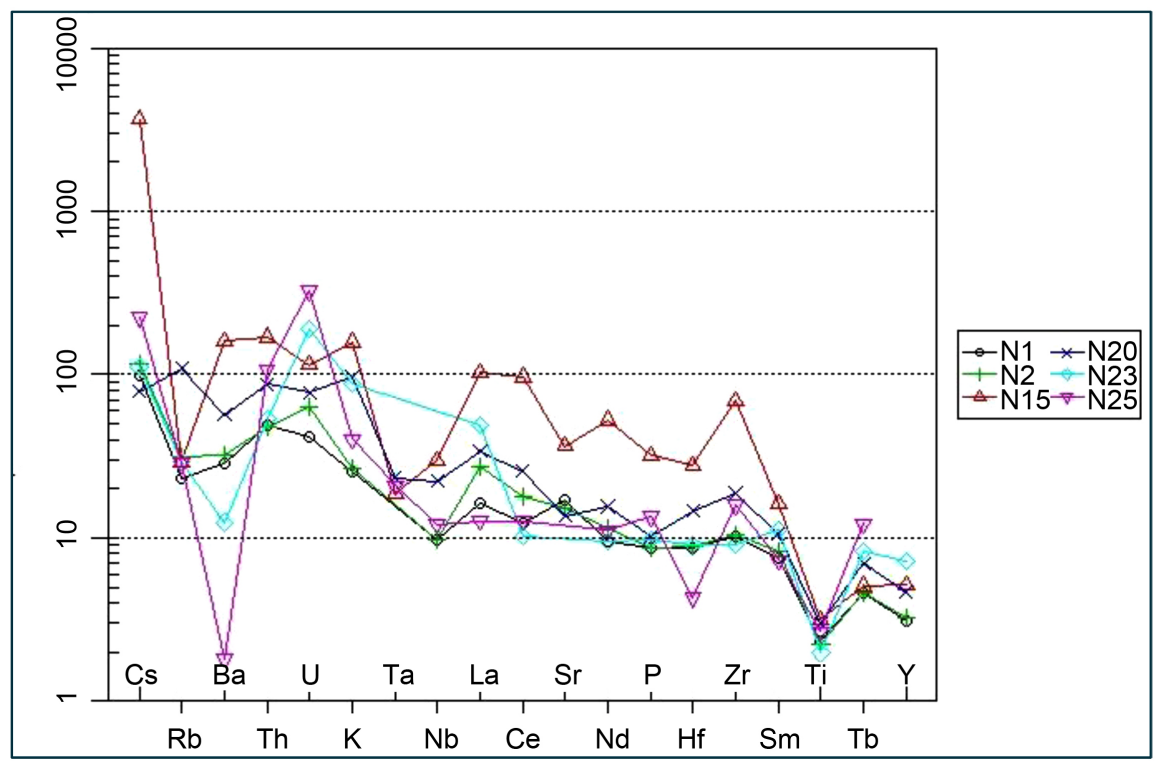

Figure 15. Spider plot-Primordial mantle (Wood et al. 1979).

which indicate intense leaching of $\mathrm{Fe}, \mathrm{Mg}, \mathrm{Mn}, \mathrm{Na}, \mathrm{K}$ and concentration in the $\mathrm{SiO}_{2}$ and $\mathrm{Al}_{2} \mathrm{O}_{3}$ respectively. This concentration in the $\mathrm{SiO}_{2}$ and $\mathrm{Al}_{2} \mathrm{O}_{3}$ led to advanced argillic and silicic alterations plot in the same field in the AKF diagram (Mus-Kao-Mont field). In the AKF diagram, the intermediate argillic an sericitic alteration are restricted to center of diagram in the Mus-Mont-Ch field. The host rock and some sample from margin of argillic zone are plotting on AKF ternary diagram. It shows that all samples fall in serecitic field. This is due to abundant of fresh feldespat in the host rock and abundance of chlorite in the propylitic alteration zones. The most of Nahran altered rocks is located in the intermediate and advanced argillation field. The middle part of Nahran is intermediate argillic. The silicic cap rock represent the advanced argillic alteration which indicate high leaching of alkaline, earth alkaline and other fero-manyasiom elements (Figure 16).

-The Q-P binary diagram.

Cunney et al. (1989) proposed a classification scheme for altered rocks based upon their cation proportions. The $\mathrm{Q}$ and $\mathrm{P}$ parameters are defined as:

$$
\begin{gathered}
\mathrm{Q}=\mathrm{Si} / 3-(\mathrm{K}+\mathrm{Na}+2 / 3 \mathrm{Ca}) . \\
\mathrm{P}=\mathrm{K}-(\mathrm{Na}+\mathrm{Ca}) .
\end{gathered}
$$

The advantage of Q-P diagram respect to De La Roche diagram is using of some of active element in the alteration zones as $\mathrm{Ca}$ in the cation calculation. The intermediate argillic alteration filed is in the center of Q-P diagram and divided to $\mathrm{K}$ metasomatism (arrow number 4) and Na metasomatism (arrow number 1) parts. The sodic metasomatism is happen contemporaneously or following the dequartzfication. Advanced argillic alteration represents an extreme form of base leaching where rocks have been stripped of alkali and feroman izian elemets elements and concentration $\mathrm{SiO}_{2}$ and $\mathrm{Al}_{2} \mathrm{O}_{3}$ of by very acidic fluids active in high flu$\mathrm{id} /$ rock ratio environments. Therefore, the silicic and advanced argillic alteration 


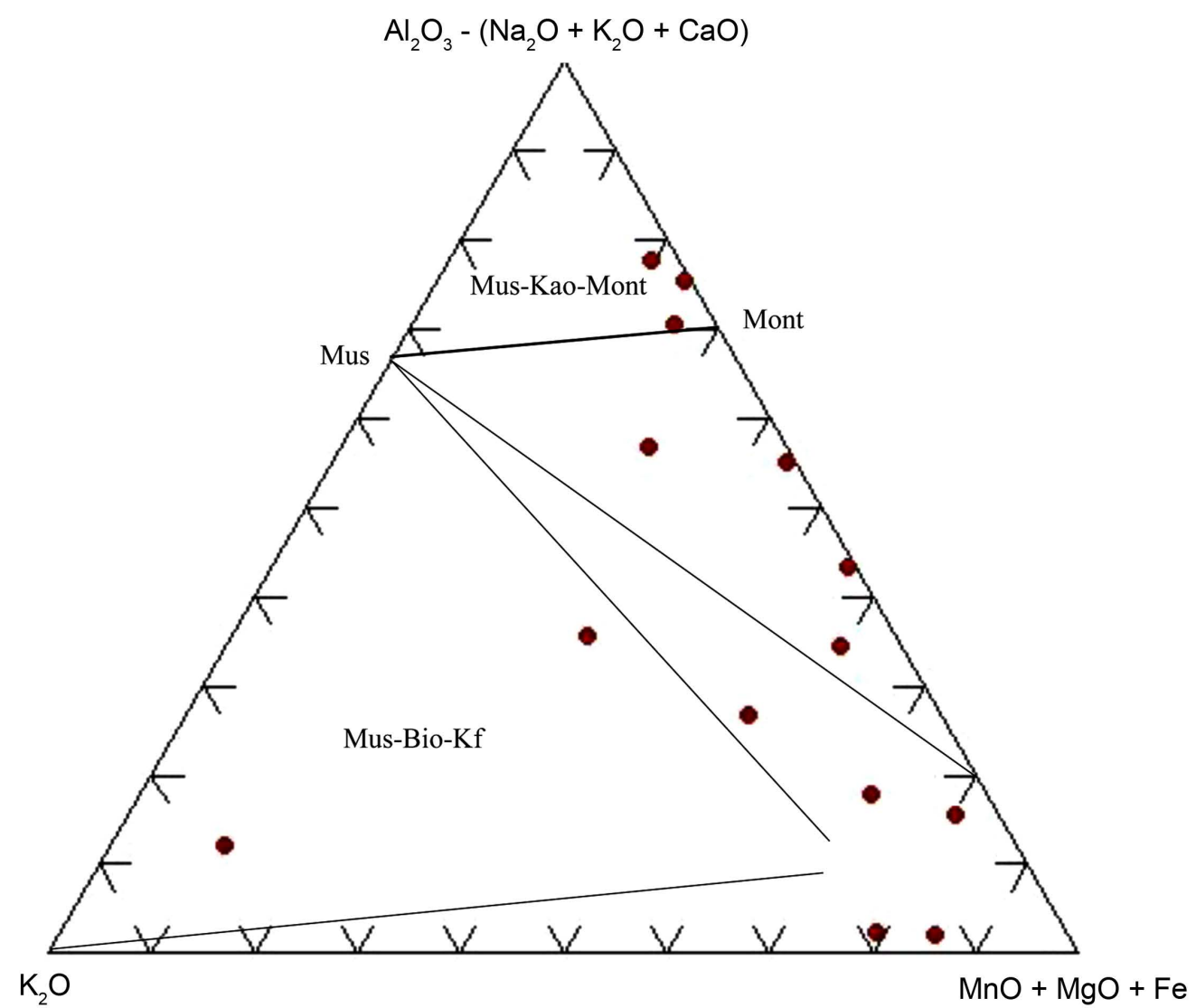

Figure 16. Opportunity altered samples of Nahran in the diagram AKF.

samples plotted in the upper part of Q-P diagram. From bottom of Q-P diagram to upper part the alkali, earth alkali and feromanyasian elements decrease and $\mathrm{Si}$ and $\mathrm{Al}$ content increase. The study of variation of Q-P parameter in the Nahran altered rock indicates that the host rocks show $\mathrm{Na}$-metasomatismed intermediate argillic alteration associated with dequartzfication. However, there is dequartzfication after intermediate argillic alteration and advanced argillic and silicic alteration in the Nahran area (Figure 17).

-The Na-K diagram.

Cunney et al. (1989) proposed a $\mathrm{Na}-\mathrm{K}$ diagram which can discriminate different alterations zones such as argillic, potassic, Sodic and Dequartzification alterations. This diagram on the basis of $\mathrm{Na}$ and $\mathrm{K}$ variations divided to segment. The K-metasomatism field restricted to left segment of diagram, where the K increase and $\mathrm{Na}$ decrease. The right segment of diagram shows Na-metasomatism field where the $\mathrm{Na}$ increase and $\mathrm{K}$ decrease. The argillic alteration field restricted to lower part of $\mathrm{Na}-\mathrm{K}$ binary diagram that indicated high $\mathrm{Na}$ and $\mathrm{K}$ leaching conditions of altered rocks. However, the intermediate argillic samples plotted in the lower part of diagram whereas advanced argillic samples due to high $\mathrm{Na}$ and $\mathrm{K}$ leaching is plotting in the center of diagram. Peyrovan (1992) [2] divided argillic alteration field to three parts such as:

1) Advanced argillic alteration with $\mathrm{Na}+\mathrm{K}$ content between $0 \%$ to $2 \%$.

2) Intermediate argillic alteration with $\mathrm{Na}+\mathrm{K}$ content between $2 \%$ to $4 \%$. 


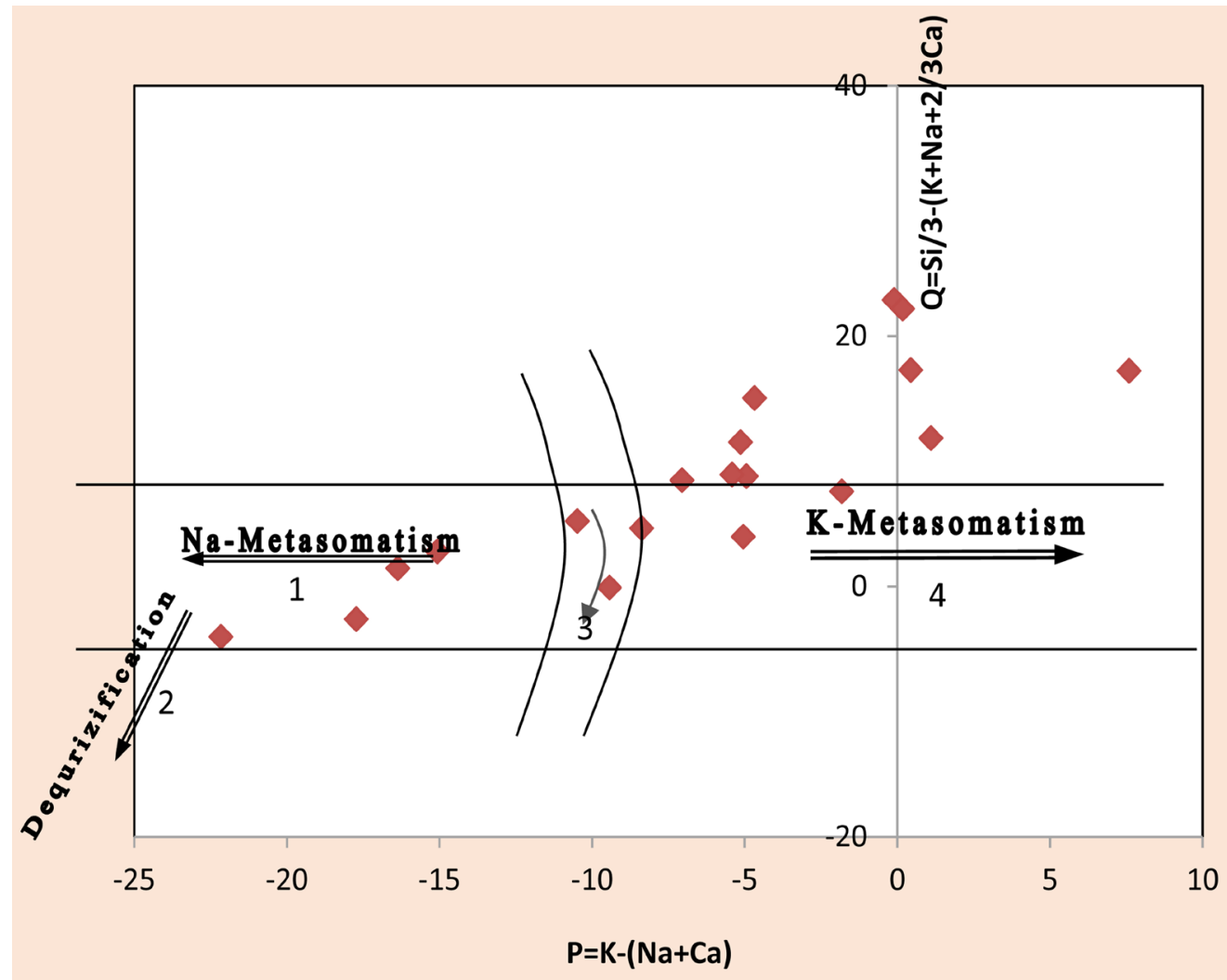

Figure 17. The position of Nahran alteration zone in the diagram Q-P, Cunney et al. (1989).

3) Weak argillic alteration with $\mathrm{Na}+\mathrm{K}$ content between $4 \%$ to $6 \%$.

The dequartzification filed is restricted to right segment of $\mathrm{Na}-\mathrm{K}$ diagram where the $\mathrm{Na}+\mathrm{K}$ content of samples are more of 7 . In the $\mathrm{Na}+\mathrm{K}$ diagram, the Nahran alteration samples located in argillation field toward the K-metasomatism and $\mathrm{Na}$-metasomatism field this consistent with high leaching of $\mathrm{Na}$ and $\mathrm{K}$ by hydrothermal and supergene fluids (Figure 18).

\subsection{Determination of Mineralization}

In order to evaluate of chemical characteristics of fluids associated with alteration episodes several discriminate diagrams have been tested for Nahran samples. According to studies [22] [23], the $\mathrm{Ba}+\mathrm{Sr} / \mathrm{Ce}+\mathrm{Y}+\mathrm{La}, \mathrm{Zr} / \mathrm{Ti}$ and $\mathrm{Cr}+\mathrm{Nb} / \mathrm{Ti}+\mathrm{Fe}$ ratios could be used for determine the role of Hypogene and Supergene processes in the genesis of Kaolins.

- The $\mathrm{Ba}+\mathrm{Sr}$ versus $\mathrm{Ce}+\mathrm{Y}+$ La binary diagram.

The $\mathrm{Ba}+\mathrm{Sr}$ versus $\mathrm{Ce}+\mathrm{Y}+\mathrm{La}$ binary diagram are used for discrimination between hypogene and supergene kaolins. The high $\mathrm{Ba}+\mathrm{Sr}$ ratios (up to 1000 to $10,000 \mathrm{ppm}$ ) represent Presence of barite which is common on the hypogene kaolin deposit [23]. Minor elements such as Ce, Y and La concentrated in the supergene kaolans, these means that high $\mathrm{Ba}+\mathrm{Sr}$ ratio indicator of Hypogene Kaolins whilese high $\mathrm{Ce}+\mathrm{Y}+\mathrm{La}$ ratio of kaolins indicate that the Kaolin was generated from supergene fluids [24]. In the the $\mathrm{Ba}+\mathrm{Sr}$ versus $\mathrm{Ce}+\mathrm{Y}+\mathrm{La}$ binary diagram studied samples fall in the field of both hypogene and supergene fields 


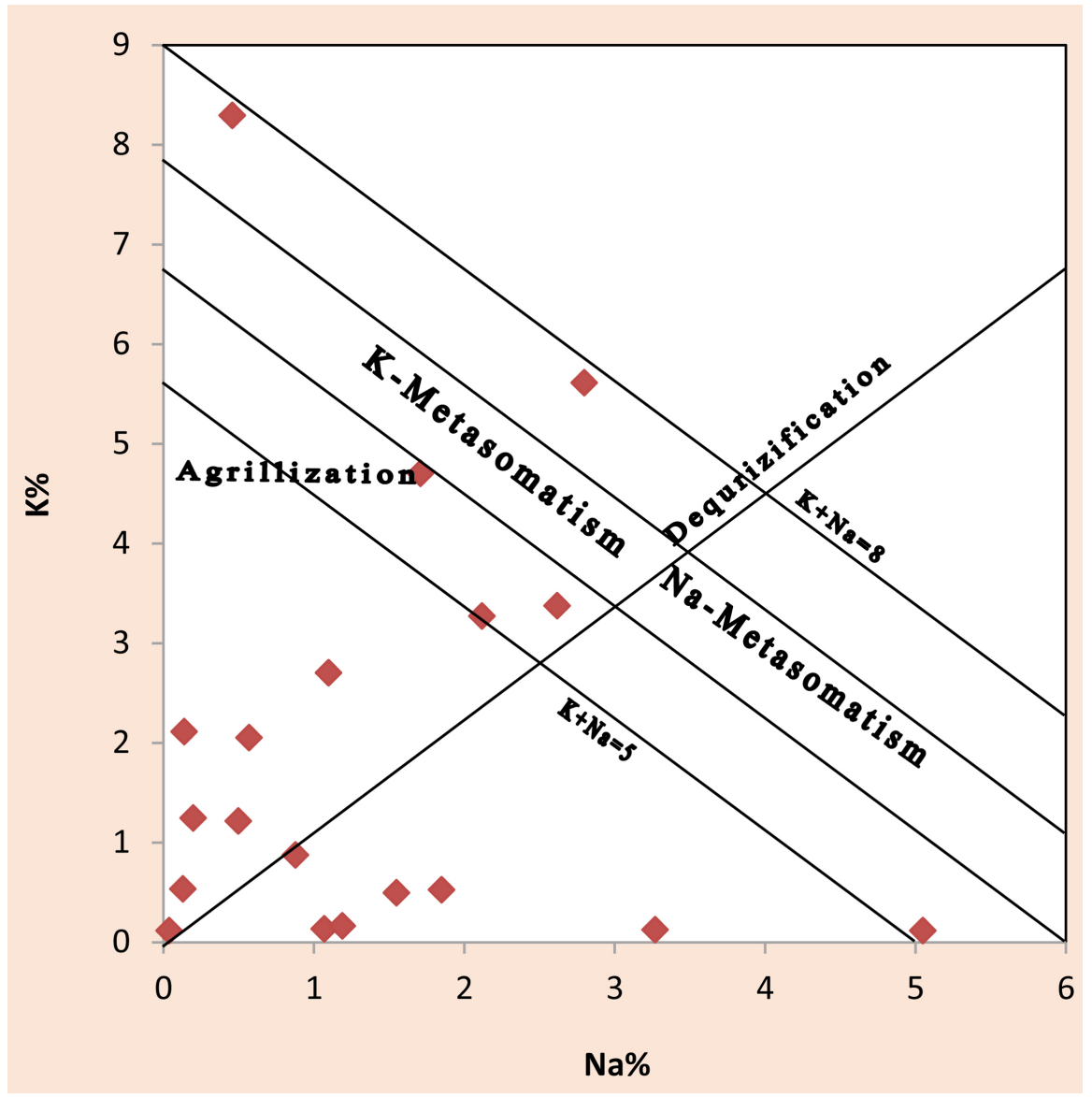

Figure 18. The position of Nahran alteration zone in the diagram Na-K, Cunney et al. (1989).

which represent effect of hypogene and supergene processes in the kaolin mineralization (Figure 19).

$-\mathrm{The} \mathrm{Ti}+\mathrm{Fe}$ versus $\mathrm{Cr}+\mathrm{Nb}$ binary diagram.

The $\mathrm{Ti}+\mathrm{Fe}$ versus $\mathrm{Cr}+\mathrm{Nb}$ binary diagram can be used to distinguish supergene from hypogene kaolinization [24]. The supergene kaolin deposit has high content of $\mathrm{Cr}$ and $\mathrm{Nb}(\mathrm{Cr}+\mathrm{Nb}>100)$ respect to hypogene deposits. The $\mathrm{Cr}$ during the supergene alteration could be substitute of $\mathrm{Ti}^{4+}$ and $\mathrm{Fe}^{3+}$ in the geotite lattice. $\mathrm{Nb}$ is known to be concentrated in Ti minerals as well, due to the similar ionic radii. The preferred concentrations of $\mathrm{Fe}$ and $\mathrm{Ti}$ in the supergene kaolins led to enrichment of $\mathrm{Ti}+\mathrm{Fe}(\mathrm{Ti}+\mathrm{Fe}>1 \mathrm{wt} \%)$ supergene kaolins. Therefore, the high $\mathrm{Ti}+\mathrm{Fe}$ and $\mathrm{Cr}+\mathrm{Nb}$ represent supergene kaolin deposits. The Nahran Kaolins show both hypogene and supergene kaolan deposits in the the $\mathrm{Ti}+\mathrm{Fe}$ versus $\mathrm{Cr}+\mathrm{Nb}$ binary diagram (Figure 20).

- The $\mathrm{Zr} / \mathrm{Ti}$ diagram.

The $\mathrm{Zr} / \mathrm{Ti}$ diagram is very useful for determination of genesis of hydrothermal deposits. The $\mathrm{Ti}$ and $\mathrm{Zr}$ are very resistant in the supergene condition and their high content in Kaolin can be used as an indicator of supergene alteration. Hovewer, $\mathrm{Ti}$ and $\mathrm{Zr}$ concentrate in the supergene alteration condition and their high cintent indicate supergene environments [23]. In the $\mathrm{Zr} / \mathrm{Ti}$ binary diagram, 


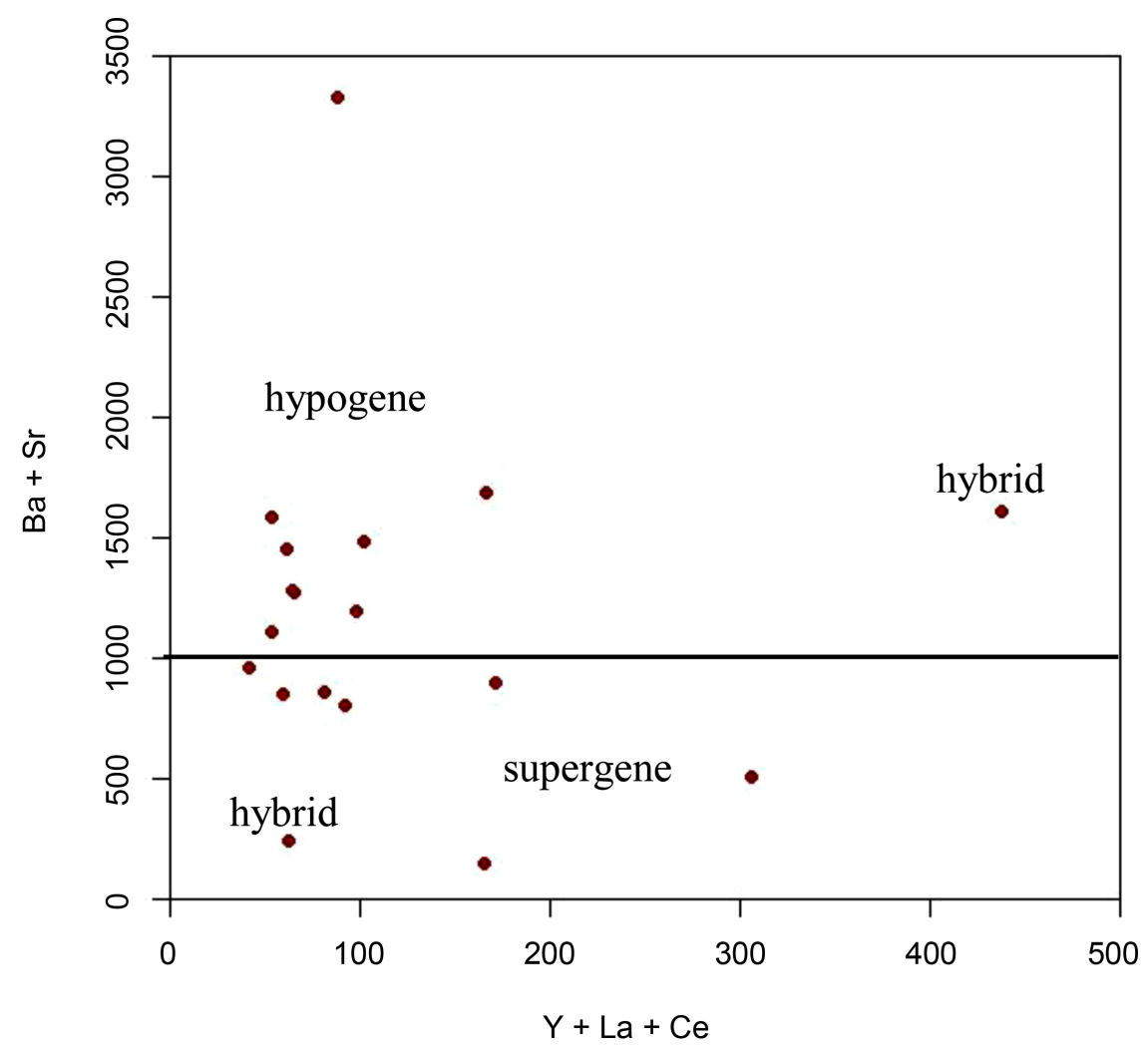

Figure 19. The $\mathrm{Ba}+\mathrm{Sr}$ versus $\mathrm{Ce}+\mathrm{Y}+\mathrm{La}$ binary diagram, (Maiza et al., 2005).

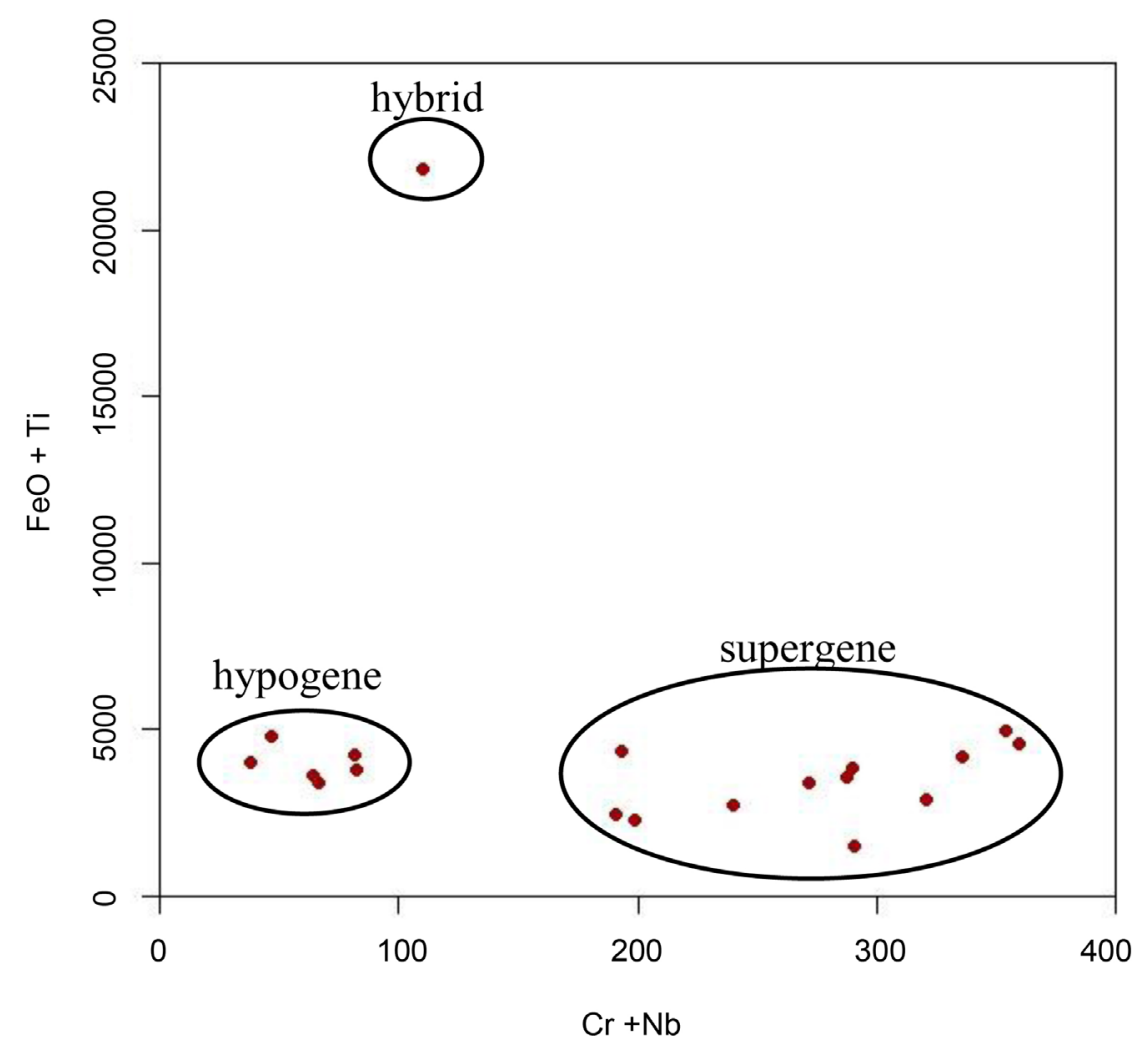

Figure 20. The $\mathrm{Ti}+\mathrm{Fe}$ versus $\mathrm{Cr}+\mathrm{Nb}$ binary diagram, (Marfil et al., 2005; Dill et al., 1997). 
Nahran Kaolin samples fall in the both supergene and hypogene field (Figure 21).

- The $\mathrm{Pb}-\mathrm{Ba}+\mathrm{Sr}-\mathrm{Ce}+\mathrm{Y}+\mathrm{La}$ ternary diagram.

$\mathrm{The} \mathrm{Pb}-\mathrm{Ba}+\mathrm{Sr}-\mathrm{Ce}+\mathrm{Y}+\mathrm{La}$ ternary diagram are used for determination of physic-chemical properties of mineralization fluids. $\mathrm{Pb}$ is derived from decomposition of K-feldspar in the bedrock; however, it is very low in the weathering zone. $\mathrm{Pb}$ does not substitute for other cations in the APS (aluminium, Phosphate, sulphate) minerals but can replace $\mathrm{Ba}$ in barite. The $\mathrm{Pb}$ represent of plumbogummite [24]. Plumbogummite was not detected in the Nahra deposit. All Nahran samples lay away from $\mathrm{Pb}$ and arrange parallel to the $\mathrm{Ba}+\mathrm{Sr}-\mathrm{Ce}+$ $\mathrm{Y}+\mathrm{La}$ side in the $\mathrm{Pb}-\mathrm{Ba}+\mathrm{Sr}-\mathrm{Ce}+\mathrm{Y}+\mathrm{La}$ ternary diagram. The proximity of some samples to $\mathrm{Ba}+\mathrm{Sr}$ side indicates their hypogene source and supergene for $\mathrm{Ce}+\mathrm{Y}+\mathrm{La}$ side adjacency samples (Figure 22).

-The $\mathrm{SO}_{3} / \mathrm{P}_{2} \mathrm{O}_{5}$ discriminate diagram.

In the $\mathrm{SO}_{3} / \mathrm{P}_{2} \mathrm{O}_{5}$ discriminate diagram, high $\mathrm{SO}_{3}$ content indicate sulfide rich

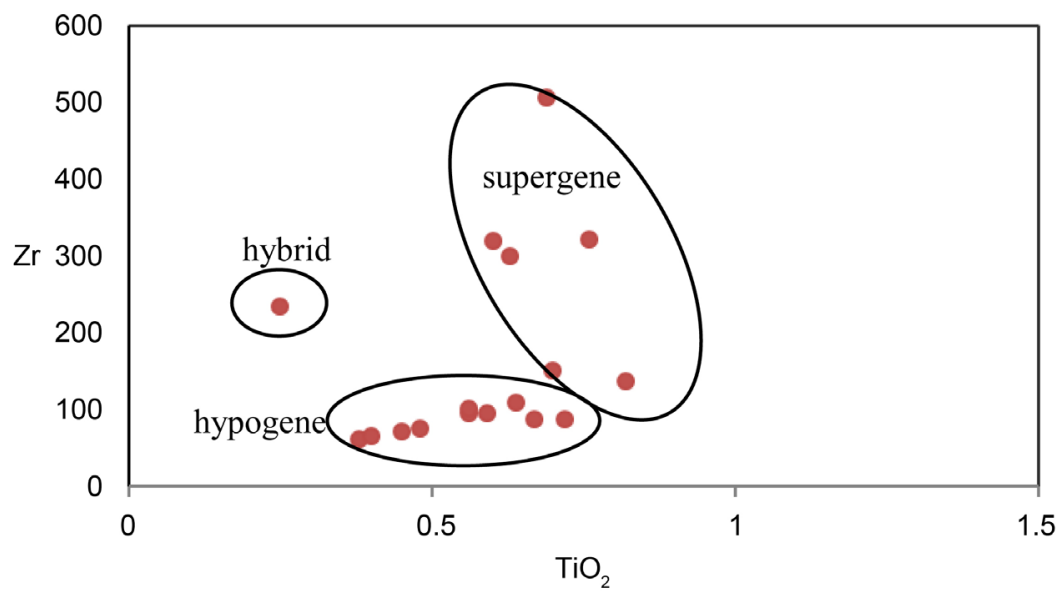

Figure 21. The Zr/Ti diagram.

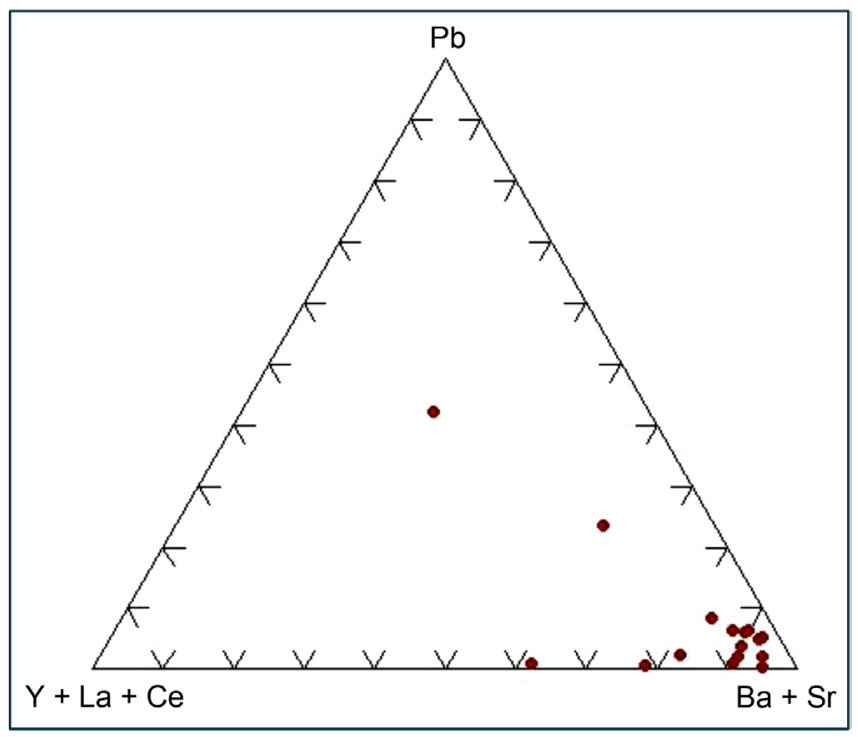

Figure 22. $\mathrm{The} \mathrm{Pb}-\mathrm{Ba}+\mathrm{Sr}-\mathrm{Ce}+\mathrm{Y}+\mathrm{La}$ ternary diagram. 
hydrothermal fluids. $\mathrm{SO}_{3}$ rich kaolins are typical of hypogene alteration, whereas in the Supergene deposits $\mathrm{P}_{2} \mathrm{O}_{5}$ is also more abundant and increases with the degree of alteration. The $\mathrm{SO}_{3} / \mathrm{P}_{2} \mathrm{O}_{5}$ diagram show the alteration in the Nahran area sormed from both hypogene and supergene fluids (Figure 23).

\section{Conclusion}

The Nahran area is located in the Northeast of Zanjan in the Northwest of Iran. This area with $20,000 \mathrm{~km}^{2}$ is part of Tarom volcanic-plutonic zone which lies between the longitudes $49^{\circ} 7^{\prime} 7.80^{\prime \prime} \mathrm{E}$ and $36^{\circ} 41^{\prime} 25.74^{\prime \prime} \mathrm{E}$ near to Nahran village. Based on mineralogical studies, several alteration units and seven alteration zones of propylitic-chloritic intermediate argillic, advanced argillic, aluinte and silicic zones are identified in the Nahran area. The geochemical studies indicate host rocks of Nahran alteration area are andesite, trachy-andesite and dacite which have high-K calc-alkaline and shoshonite affinity. These rocks represent most similarity to orogenic and islands of mid ocean spreading center basalts (oceanic island alkaline basalt and calc-alkaline basalts). The Nahran volcanic rocks have metaluminus and peraluminus affinity. Chonderite normalized spider pattern of Nahran volcanic rocks shows relative enrichment in the LREE respect to HREE with positive Eu anomaly. In the Primitive mantle and MORB normalized diagram, the Nahran volcanic rocks display relative enrichment in the compitable element. These indicate the role of crustal contamination or other primary magma contaminative processes in the magmatic evolution of $\mathrm{Na}$ hran volcanic rocks. The study of variation of Q-P parameter in the Nahran altered rock indicates that the host rocks show Na-metasomatismed intermediate argillic alteration associated with dequartzfication. Diagram Na-K, showing argillic Potassic and Sodic alteration which represents the exit of potassium and sodium from the rock environment is by hydrothermal solutions. In order to evaluate chemical characteristics of fluids associated with alteration episodes, several discriminate diagrams such as $\mathrm{Ba}+\mathrm{Sr} / \mathrm{Ce}+\mathrm{Y}+\mathrm{La}, \mathrm{Zr} / \mathrm{Ti}$ and $\mathrm{Cr}+\mathrm{Nb} / \mathrm{Ti}+\mathrm{Fe}$ have been tested for Nahran samples. These diagrams indicate both supergene

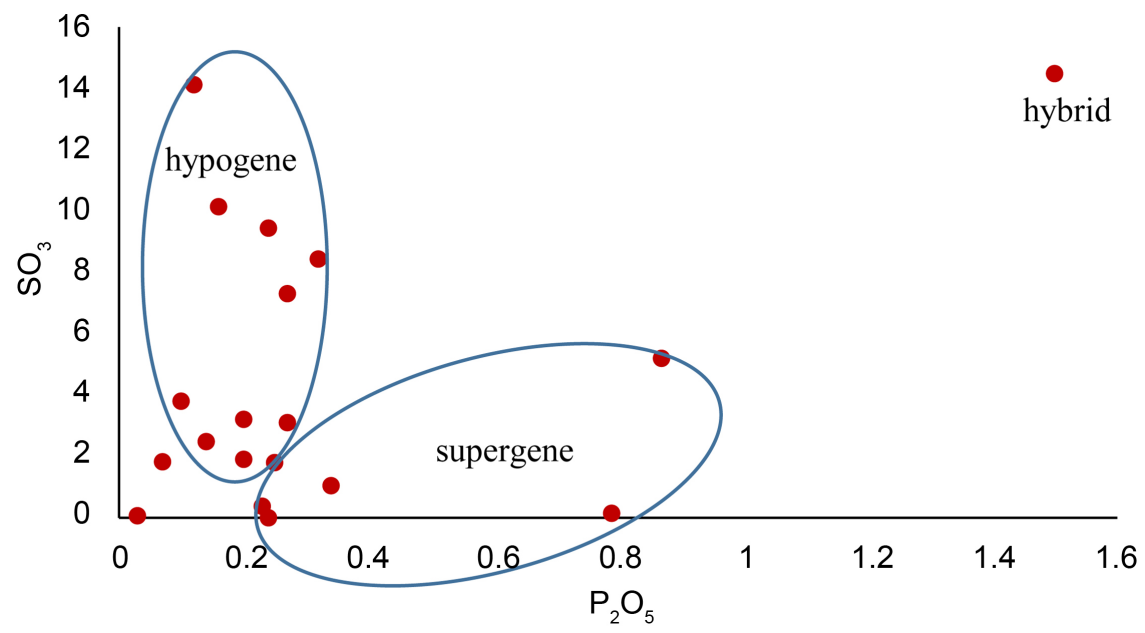

Figure 23. The $\mathrm{SO}_{3} / \mathrm{P}_{2} \mathrm{O}_{5}$ discriminate diagram. 
and hypogene process have an effective role in the development of alteration in the Nahran area. In the $\mathrm{SO}_{3} / \mathrm{P}_{2} \mathrm{O}_{5}$ discriminate diagram, high $\mathrm{SO}_{3}$ content indicates sulfide rich hydrothermal fluids.

\section{References}

[1] Nabavi M.H., (1976) The history of the Geological Survey of Iran, Geological Survey of Iran, 109 Page.

[2] Peyrowan, H.( 1992) petrography, petrology and Geochemistry of intrusive igneous rocks in the North Abhar with special reference to mineralization, Msc thesis, teacher training university, Tehran, Iran.

[3] Geological survey of Iran 1969. Explanatory text of the Zanjan Quadrangle Map, 1: 250000, No.D4.

[4] Geological survey of Iran 1975. Explanatory text of the Qazvin - Rasht Quadrangle Map, 1: 250000, Nos.E3, E4.

[5] Hirayama,K., Zahedi, M. Hoshmandzadeh,A. 1964. Geology of the Zanjan area: The Tarom district,western part, No.8, Geol.Survey of Iran.

[6] Hirayama, K. Haghipour, A. Hajian, J. 1965. Geology of the Zanjan area:The Tarom district,eastern part. No.28, 33p. With Map 1:100000. Geol.Survey of Iran.

[7] Middlemost E.A.K., 1975, The basalt clan. Earth Sci. Rev., 11, 337-364.

[8] Middlemost E.A.K., 1985, Magmas and magmatic rocks. Longman, London.

[9] Middlemost E.A.K., 1989, Iron oxidation ratios, norms and the classification of volcanic rocks. Chem. Geol., 77, 19-26.

[10] Winchester J.A. and Floyd P.A., 1977, Geochemical discrimination of different magma series their differentiation products using immobile elements. Chem. Geol., 20, 325-345.

[11] Kuno H., 1968, Differentiation of basalt magmas. In: Hess H.H. and Poldervaart A. (eds.), Basalts: The Poldervaart treatise on rocks of basaltic composition, VOL. 2. Interscience, New York, pp. 623-688.

[12] Irvine T.N. and Baragar W.R.A.,1971, A guide to the chemical classification of the common volcanic rocks. Can. J.Earth Sci., 8, 523-548.

[13] Thompson R.N., Morrison M.A., Hendry G.L. and Parry S.J., 1984, An assessment of the relative roles of crust and mantle in magma genesis: an elemental approach. Phil. Trans. R. Soc., A310, 549-590.

[14] Thompson R.N., 1984, Dispatches from the basalt front. 1. Experiments. Proc. Geol. Ass., 95, 249-262.

[15] Thompson R.N., 1982, British Tertiary volcanic province. Scott. J. Geol., 18, 49-107.

[16] Pearce J.A., 1983, Role of the sub-continental lithosphere in magma genesis at active continental margins. In: Hawkesworth C.J. and Norry M.J. (eds), Continental basalts and mantle xenoliths. Shiva, Nantwich, pp. 230-249.

[17] Rollinson, Hugh. R. (1993), Using Geochemical Data, Longman Scientific \& Technical.

[18] Wood D.A., Joron J.L., Treuil M., Norry M. and Tarney J., 1979a, Elemental and Sr isotope variations in basic lavas from Iceland and the surrounding ocean floor. Contrib. Mineral. Petrol., 70, 319-339.

[19] Wood D.A., Tarney J., Varet J., Saunders A.D., Bougault H., Joron J.L., Treuil M. and Cann J.R., 1979b, Geochemistry of basalts drilled in the North Atlantic by IPOD Leg 49: implications for mantle heterogeneity. Earth Planet. Sci. Lett., 42, 
77-97.

[20] Wood D.A., Joron J.L., Treuil M., 1979c, A re-appraisal of the use of trace elements to classify and discriminate between magma series erupted in different tectonic settings.Earth Planet. Sci. Let., 45, 326-336.

[21] Wilson M., 1989, Igneous petrogenesis. Unwin Hyman, London.

[22] Marfil, S. and Maiza, P. (2012) Geochemistry of Hydrothermal Alteration in Volcanic Rocks, Universidad Nacional del Sur-INGEOSUR_CIC de la Provincia de Buenos Aires-CONICET Argentina.

[23] Maiza P. J., Pieroni D., Marfil S. A.,"Geochemistry of hydrothermal kaolins in the SE area of Los Menucos, Province of Rlo Negro, Argentina", In: Dominguez, E.A., Mas, G.R., Cravero, F. (Eds.), 2001, A Clay Odyssey Elsevier, Amsterdam (2003) 123-130

[24] Marfil, S. A. Origin of kaolin deposits in the "LosMenucos" area, Rõ Âo Negro Province, Argentina, Clay Minerals (2005) 40, 283 \pm 293

Submit or recommend next manuscript to SCIRP and we will provide best service for you:

Accepting pre-submission inquiries through Email, Facebook, LinkedIn, Twitter, etc. A wide selection of journals (inclusive of 9 subjects, more than 200 journals)

Providing 24-hour high-quality service

User-friendly online submission system

Fair and swift peer-review system

Efficient typesetting and proofreading procedure

Display of the result of downloads and visits, as well as the number of cited articles

Maximum dissemination of your research work

Submit your manuscript at: http://papersubmission.scirp.org/

Or contact ojg@scirp.org 